\title{
El Quijote, guardián del secreto español en Ortega
}

("Don Quijote (...) es como un guardián del secreto español”).

\section{LAS MEDITACIONES DEL QUIJOTE DE ORTEGA}

\section{Introducción}

Según el crítico literario José-Carlos Mainer, el Quijote sería: “un emblema del desasosiego nacional"1. Para este autor, fue José Cadalso, en sus Cartas Marruecas, el primero que indicó que en ese libro, que parece de burlas, con una serie de "extravagancias de un loco" y "algunas sentencias en boca de un necio" y mucha crítica de la vida, "lo que hay debajo de esa apariencia, en mi concepto, es un conjunto de materias profundas e importantes" (Carta LXI). Tan importantes que Mainer se pregunta: “Al hablar del 'Quijote', ¿de qué hablamos? ¿De una obra que dictó espontáneamente el espíritu de España o de un escritor que lo imaginó?": M1.

Azorín en La ruta de don Quijote y Unamuno en La vida de don Quijote y Sancho, desarrollan ese tema como ha escrito sabiamente, para Unamuno, F. de Ayala en su invención del Quijote ${ }^{2}$. También $\mathrm{M}^{\mathrm{a}}$. Bengoa, abunda en esta dirección: Unamuno enlaza su comprensión del Quijote con "su visión particular del problema de España". Esa misma preocupación "por el destino de España, de todo un pueblo", en la lectura de Unamuno, la recuerda J. M. Blecua Perdices.

1 J.C. MAINER, En la literatura del siglo XX. Un lugar en la memoria. De Azorín a Luis Mateo Diez. El Norte de Castilla 24.12.2004, 1. Remarcado nuestro. En adelante M.

2 Cf. D. NATAL, El Quijote o la Filosofía española según Unamuno, Religión y Cultura, $52(2006) 3$. 
Estando así las cosas, J. C. Mainer sentencia: "En 1914, Ortega publicó sus Meditaciones del Quijote que son, amén de otras cosas imprescindibles para la historia intelectual de España, una reivindicación del Quijote como obra de arte y, por ende, de Cervantes como autor del milagro": M3. Para Mainer, sin la obra de Ortega, no se entendería el gran ensayo de A. Castro, 'El pensamiento de Cervantes' (1925), sobre la configuración espiritual del autor del Quijote.

Pero, además de la crítica literaria, continúa Mainer, está la emulación del Quijote como acontece en Juegos de la edad tardía de Luis Landero o en algunas novelas de Luis Mateo Díez. Y termina nuestro autor: "Por ahí seguramente no acabaríamos nunca... Y ojalá no acabemos". Por su parte Luis Martín Santos, en su famosa novela Tiempo de Silencio, ya se había preguntado si podía haber existido, realmente, en el viejo lugarón de Madrid, un hombre como Cervantes "que tuviera esa visión de lo humano, esa creencia en la libertad, esa melancolía desengañada tan lejana de todo heroísmo como de toda exageración, de todo fanatismo como de toda certeza": M1. El erudito español, Mayans y Siscar, que con su Vida de Miguel de Cervantes inició el cervantismo, aseguraba: "Don Quijote es hombre de todos los tiempos y verdadera idea de todos los que ha habido, hay y habrá, y así se acomoda bien a todos los tiempos y lugares"3.

Para M. Vargas Llosa, "el Quijote es un canto a la libertad"4, se trata de una novela para hombres libres que presenta la vida humana en su "infinita sutileza y diversidad" con una visión "libérrima de la justicia". Según Elena Santiago: "Habita don Quijote páginas que son aliento de necesidad de libertad, amor y justicia. Así, no habrá aventura noble sin ejercer los derechos humanos. Sus días y delirios son páginas de profunda enseñanza, regalo de una gran verdad".

Finalmente, para Francisco Rico, la concepción romántica del Quijote lo idealiza, atenúa el "carácter cómico de la novela, para entenderla como un símbolo de las relaciones entre el individuo y la realidad, o de España y los españoles, amoldándola a las ideologías de la Edad Contemporánea"5. Para F. Rico el verdadero Quijote es la síntesis de todas sus interpretaciones.

\footnotetext{
${ }^{3}$ A. MESTRE, Mayans y la España de la Ilustración. Madrid 1990, 73.

${ }^{4}$ M.VARgas Llosa, Una novela para el siglo XXI, en M. de Cervantes, Don Quijote de la Mancha. Ed. IV Centenario, Madrid 2004, XVIII.

5 F. RICO, Tantos 'quijotes', Babelia, El País (15.10.2005)10. Comentario a A. J. CLOSE, La concepción romántica del 'Quijote'. Barcelona 2005.
} 


\section{0. Ortega ante el Quijote y el problema de España}

Todos los ensayos de Ortega "acaban por referirse a las circunstancias españolas"6. Aquí, se trata de "unos ensayos de amor intelectual", en términos que usó Spinoza, y podemos llamarlos "salvaciones" porque tratan de llevar las cosas o acontecimientos analizados "a la plenitud de su significado". Pues cada cosa o persona guarda en su interior "una posible plenitud"que es como un hada madrina, y el alma noble abierta trata de auxiliarla para que llegue a lograrla. "Y esto es amor -el amor a la perfección del amado". Rembrandt es un ejemplo permanente de todo esto. Sus cuadros envuelven, en una atmósfera radiante, las cosas más ordinarias. Así parece decirnos: “iSantificadas sean las cosas! ¡Amadlas, amadlas”: Q47. Envuelto en esta atmósfera, el misterio de las cosas queda "transfigurado, transubstanciado, salvado".

Por eso, en estos ensayos de Ortega hay siempre "una doctrina de amor". Y quiere hacerlo así porque Ortega sospecha que la morada de los españoles ha sido conquistada, hace tiempo, "por el odio" que permanece allí enquistado, aniquila todo valor, y produce una realidad agria, sórdida y desierta como narra Mateo Alemán en su alegoría del Descontento. Por el contrario, el amor nos liga y une a la cosas, nos las hace imprescindibles. Ese ligamen y compenetración nos lleva a internarnos profundamente en la realidad amada, para que podamos verla entera y, así, "se nos revela en todo su valor". El amor, ligando todo, es, como dijo Platón, un gran arquitecto que bajó al mundo para que "todo en el universo viva en conexión". Al contrario, el odio aísla, atomiza y destruye toda relación amorosa.

Ahora bien, según Ortega: "Los españoles ofrecemos a la vida un corazón blindado de rencor, y las cosas, rebotando en él, son despedidas cruelmente. Hay en derredor nuestro, desde hace siglos, un incesante y progresivo derrumbamiento de los valores": Q49. El rencor destruye todo. De ahí que Ortega pide a las generaciones jóvenes que expulsen el odio de sus vidas y aspiren a que el amor vuelva a regir el mundo. Para ello, él, intentará contagiar, el alma española, con una clave amorosa: "el afán de comprensión" que es una "locura de amor" al servicio de la vida. Por el contrario, el rencor, como ya había visto Nietzsche, nos impide ver la realidad, simplifica la vida aniquilando "porciones inmensas del orbe", incluidos los humanos que no son como nosotros. Comprender al enemigo, he ahí la verdadera tolerancia. Pero esta virtud es poco frecuente en los pueblos pobres y sin energía: "Es decir, en los pueblos débiles".

\footnotetext{
6 J. ORTEGA Y GASSET, Meditaciones del Quijote. Cátedra, Madrid 2001, 5a , 44. En adelante $\mathrm{Q}$.
} 
Ortega describe con más detalle, en un escrito sobre Zuloaga, este carácter español, áspero, bárbaro e inculto. Dice Ortega que Zuloaga pinta la fuerza viva de la cosas poseídas por el Espíritu. Así, el arte es "sensibilidad para lo necesario". Como diría Valle-Inclán: "El arte es el arte de lo eterno, de lo que no tiene edad"'. Así, en el cuadro de Gregorio el Botero, Zuloaga pinta el mito español que, en su fórmula extrema, dice: España se ha negado a aceptar los cambios sociales, morales e intelectuales propios de la Edad Moderna. La historia moderna de España sería "la historia de su resistencia a la cultura moderna", y así sería: "la única raza europea que ha resistido a Europa":B543. Este es, realmente, independientemente del juicio que nos merezca, un tema trágico, "eterno y necesario".

Zuloaga es un gran artista que ha sido muy capaz de "sensibilizar el trágico tema español". Por sus cuadros corre un aire "irresistible, aterrador y bárbaro" que parece llegar de "inhóspitos desiertos", otras, es un viento "frígido" venido de los más fieros "ventisqueros". Así, en el cuadro del enano G. el Botero, nos muestra esa sensibilidad brutal, captada en un solo hombre, en el que se integran personajes de tierras muy diferentes pero que tienen un destino común: "morir sobre la tierra por aspirar a conservarse idénticos":B544. Estamos ante una "vitalidad belicosa" que se niega a progresar, a actualizarse, cultivarse y afinarse. Es el reino del capricho, de lo castizo frente a la racionalidad. G. el Botero es de una "simplicidad bestial", una condición casi animal que se atrinchera en "la voluntad de incultura":B544. Es un "hombre capriforme" con una "energía elemental", un "ímpetu precivilizado" que pregona este "sátiro español".

Ahora bien, si ser hombre consiste en "un perenne superarse a sí mismo", nuestro personaje hinca sus pies en al tierra y se niega todo cambio, decide quedar inculto bajo "el cielo duro, bruñido, reverberante", sometido al yugo de la fatalidad vacuna, que "pone los odios crespos y consume los nacientes pensamientos": B544. Ortega le recomienda al fatal personaje que cumpla su trágica misión, en su patria desolada, "áspera y cruda", armado con sus "pellejos berrendos", pero que tenga cuidado no sea que "revienten tus odres y las rúas se encharquen con sangre de España": B545. Esta última frase, fue una profecía de Ortega, pues lo ocurrido años más tarde es bien conocido.

Por lo demás, no es, en absoluto, ético disfrazar el desamor, y su moral utilitaria, con falsa capa de la rigidez moral que es el traje más tradicional de la hipocresía: "Es falso, es inhumano, es inmoral, filiar en la rigidez los rasgos lante $\mathrm{B}$.

7 ID., La estética de "El enano Gregorio el Botero": O. C. I., Madrid 1983, 542. En ade- 
fisiognómicos de la bondad": Q54. De ahí que la moral egoísta y cantonalista no pueda ser, en modo alguno, moral. Con razón escribía Flaubert: "El ideal solo es fecundo -entiéndase moralmente fecundo-, cuando se hace entrar todo en él. Es un trabajo de amor y no de exclusión": Q55. La moral integral, auténtica y verdadera extiende "indefinidamente nuestro radio de cordialidad", y, nuestra posibilidad "de ser justos". Ese afán de comprender es una "actitud religiosa", un imperativo moral, y es lo menos que podemos hacer, como seres humanos, para entendernos y aceptarnos todos.

Continúa Ortega: "En este sentido considero que es la filosofía la ciencia general del amor": Q55 (Remarcado nuestro). Estamos aquí ante un "ímpetu hacia una omnímoda conexión", mientras el mero saber que es pura y simple erudición da cuenta de hechos aislados, sin saber su relación, por eso decimos que es un "cajón de sastre". Pero la filosofía aspira a conseguir una síntesis integradora de las cosas para formar un universo, donde cada uno mira a los otros con respeto y aprecio mutuo. Así la filosofía es el placer de la comprensión.

Estas Meditaciones de Ortega no son propiamente filosofía, que es una ciencia, sino simplemente un ensayo que es "la ciencia, menos la prueba explícita". Y, aunque el autor tenga esa prueba y esté convencido de ella, Ortega no quiere presentar sus propuestas como una verdad apodíctica, sino que sólo ofrece modi res considerandi, una nueva manera de ver las cosas. Se trata de despertar en "almas hermanas otros pensamientos hermanos", aunque fuesen "hermanos enemigos". Hay aquí un claro llamamiento a una amplia colaboración nacional.

En estos ensayos, se meditan los grandes temas de España, pero también las cosas mínimas, los pequeños detalles en los que "se revela la intimidad de una raza". Pues el hombre rinde al máximo cuando adquiere plena conciencia de sus circunstancias, ya que por ellas se une a todo el universo. Las circunstancias son las cosas mudas junto a nosotros, a nuestro alrededor, en una cercanía humilde y generosa que espera nuestra aceptación de su amor entregado. De no hacerlo así, el héroe acabará siendo un ser inhumano que pisotea lo humilde y aniquila a sus próximos.

Según Ortega, es necesario cambiar esa sensibilidad: "Que impelía los ánimos a desatender todo lo inmediato y momentáneo de la vida". Todo lo hemos dedicado a la política, a la lucha social, a la administración, al Estado, porque nos habría parecido frívolo dedicar parte de nuestras mejores energías al cultivo de la amistad, "a construir un amor perfecto", a gozar sabiamente de la vida. Con frecuencia, hemos privado a estas experiencias, tan profundamente humanas, de carta de ciudadanía y de valor cultural, pero, hoy, necesitamos "un Newton del placer y un Kant de las ambiciones": Q68. Es cierto, 
que, en otros tiempos, todo lo individual parecía carente de importancia y significación, no habíamos extraído su verdadero sentido y con frecuencia pasaba por ser puro capricho, mera casualidad o pura ocurrencia.

De hecho, todo lo que ahora consideramos importante ha pasado antes por "el corazón del hombre", donde ha recibido su sentido y humanidad. Así, lo inmediato no se queda ensimismado, ni en la materia ni en el espíritu, sino que se orienta en una perspectiva divina que desvela su misterio. Entonces, lo sublime fecunda lo inmediato y el amor a lo menudo e insignificante da eficacia a lo sublime. Por eso, se ha dicho muy bien: "Para quien lo pequeño no es nada, no es grande lo grande".

Por tanto, no podemos permanecer hieráticos y absortos ante los grandes valores, sino que debemos integrarlos en nuestra vida diaria para dar sentido a lo que nos rodea. Pues "la reabsorción de la circunstancia es el destino concreto del hombre". Y, esa circunstancia es "la otra mitad de mi persona", y sólo a través de ella puedo "ser plenamente yo mismo". Por eso sentencia Ortega: "Yo soy yo y mi circunstancia, y si no la salva a ella no me salvo yo": Q77 (Subrayado nuestro). No hay cosa en el mundo por la que no pase "algún nervio divino”. Ya lo decía Heráclito: “Entrad, entrad! También aquí hay dioses". Y, Goethe escribe a Jacobi, que sube y baja los cerros "buscando lo divino in herbis et lapidibus": Q78-9. Para el héroe, como Moisés, toda roca es hontanar, manantial de lo divino. Por eso decía G. Bruno: est animal sanctum, sacrum et venerabile, mundus.

Azorín vio muy bien esto. La sociedad actual sólo ve las grandes cosas y parece dejar lo íntimo, incluida la inquietud sexual, para el bajo consumo ordinario. Pero eso es un grave error. De hecho cuando nos sentimos arrojados a los barrios bajos del pesimismo volvemos los ojos "hacia las menudas cosas del vivir cotidiano": el recuerdo de un amigo, el calor del hogar en el invierno, la grata sensación de una copa en compañía... Pues no son sólo las grandes cosas ni los placeres más fuertes los que nos sostienen sobre la faz de la tierra.

Respecto al pasado, otro de los "terribles morbos nacionales", tocado por Azorín, hace recordar que España es, según Kant, la "tierra de los antepasados", donde "los muertos matan a los vivos" (Las Coéforas), y los siguen gobernando: Q81. No en vano, nuestros antepasados celtíberos adoraban a la muerte. Es una cuestión muy delicada que encierra la "mecánica psicológica del reaccionarismo español", su incapacidad para buscar una tradición viva y un pasado fecundo para nuestra actualidad. Pues, como las aves mueren por los miasmas de las marismas, "cae muerto el pasado dentro de nuestras memorias". 
Con Baroja hemos de meditar sobre política, arte y un poco de todo. Porque este hombre, más que un hombre, es una encrucijada. Por lo demás, en estas críticas, Ortega, prefiere ser más amante que juez. La crítica ha de ser un esfuerzo pavoroso por potenciar la obra elegida, para completarla y proporcionarle "la atmósfera más favorable" a fin de saborearla y actualizarla.

Por lo demás, Ortega, en sus Meditaciones, va a estudiar el Quijotismo, no el del personaje sino "el quijotismo del libro". El Quijote es la "miseria ideal" del pasado, la sordidez del presente y la acre hostilidad del porvenir español en toda su crudeza. Es como la parodia triste de un Cristo divino y sereno pero dolorido que quiere dar nueva vida a los suyos. Así, don Quijote, desciende sobre los suyos, como Jesús, y al "calor fundente de su fisiognomía disparatada compagina aquellos corazones dispersos, los ensarta como en un hilo espiritual, los nacionaliza, poniendo tras sus amarguras personales un comunal dolor étnico": Q86.

Así es como Cervantes nos aleja tanto de quijotismo contorsionado, lleno de falsos espasmos, como de la dimisión del quijotismo. Pues Cervantes es el verdadero quijotismo, el verdadero azor del alma española. Pero no la ataca como a una presa, como no lo hará Ortega, sino que utilizará el método Jericó, dando vueltas en grandes círculos, que traza el pensamiento. "Fatalmente atraído por la obra inmortal", se acerca al alma del Quijote aunque renuncia a invadir sus "secretos últimos".

Por lo demás, esta obra de Ortega es un acto patriótico, porque "la negación de la España caduca" le obliga a buscar una nueva o por lo menos a intentarlo: "Así, nosotros. Habiendo negado una España, nos encontramos en el paso honroso de hallar otra. Esta empresa de honor no nos deja vivir. Por eso, si se penetrara hasta las más íntimas y personales meditaciones nuestras, se nos sorprendería haciendo con los más humildes rayicos de nuestra alma experimentos de nueva España": Q89.

\section{1. El Quijote y el enigma de España}

El gran maestro neokantiano de Ortega, H. Cohen, se había preguntado, también, en su Ética de la voluntad pura: “Es, por ventura, el don Quijote sólo una bufonada?": Q93. Y con ese lema, por bandera, entra Ortega en su meditación del bosque donde establece un profundo diálogo entre lo visible y lo invisible, entre lo real y lo irreal, lo posible y lo imposible. El bosque, en el que ahora estoy, dice Ortega, alude siempre al bosque que no veo, con su halo de misterio succiona la mirada, pues el bosque huye de nosotros, como el ciervo herido, y "está siempre un poco más allá de donde nosotros esta- 
mos". Ese halo crepuscular de invisibilidad nos conduce al misterio de las cosas, a su interioridad y profundidad. Pues cada cosa tiene su misterio (Salinas, Lorca) y el pensamiento conduce al misterio de las cosas. Por eso es alétheia o "apocalipsis, es decir, descubrimiento, revelación, propiamente des-velación, quitar el velo o cubridor": Q110.

Así se sorprende Ortega ante el misterio del bosque del Escorial, y ante el enigma de un libro que lleva en la mano: "Don Quijote, una selva ideal". "He aquí otro caso de profundidad: la de un libro, la de este libro máximo. Don Quijote es el libro escorzo por excelencia". Y, nos asegura Ortega: "Ha habido una época de la vida española en que no se quería reconocer la profundidad del Quijote": Q119. Esta época fue la Restauración, en ella “el corazón de España" apenas podía latir. F. Silvela diría que no le encontraba el pulso. Es decir: "la vida española se repliega sobre sí misma, se hace hueco de sí misma. Este vivir el hueco de la propia vida fue la Restauración": Q120. Pues, nuestra nación ha vivido más del esfuerzo que de la inteligencia, y cuando decae ese dinamismo voluntarista entra en un profundo letargo y no le queda más "función vital que la de soñar que vive".

Entonces parece que tenemos de todo: pensadores, artistas, políticos, militares, pero todo es como un sueño. Estamos ante unos partidos fantasmas, que sostienen unos gobiernos fantasmas, que creen dirigir el fantasma de la vida nacional. Una vida que sólo tiene de real "el acto que la imagina". "La Restauración, señores, fue un panorama de fantasmas, y Cánovas el gran empresario de la fantasmagoría": Q121. Se perdió la sensibilidad por todo "lo verdaderamente fuerte, excelso, plenario y profundo". Se aplaude la mediocridad, se olvidan los valores, se ciega "el fondo insobornable" de nuestra vida humana, y la España oficial se impone a la España vital.

"En estas circunstancias, ¿cómo esperar que se pusiera a Cervantes en su lugar? (...) Sin duda, la profundidad del Quijote, como toda profundidad, dista mucho de ser palmaria. Del mismo modo que hay un ver que es mirar, hay un leer que es un intelligere o leer lo de dentro, un leer pensativo. Sólo ante este se presenta el sentido profundo del Quijote": Q124. Pero los hombres de la Restauración se creían que pensar era "buscarle tres pies al gato".

Ahora bien, por el contrario, la meditación mantiene al hombre en su propio esfuerzo tenso, y, así, casi lo lleva en volandas. Incluso, al bogar en el mar de las ideas, podemos padecer un mareo intelectual. Parece que M. Pelayo quiso limitar el problema al Norte de Europa, y por eso habló de las 'nieblas germánicas' frente a la 'claridad latina'. Pero esto, para Ortega, es un error interesado, pues la cultura mediterránea es confusa, con un realismo que es puro impresionismo. 
El hombre mediterráneo, según Ortega, no piensa claro, pues prefiere "la sensación viva de la cosas" a las cosas mismas en su esencia, pero sí ve muy claro y describe con exactitud lo que ve inmediatamente. "En Cervantes esta potencia de visualidad es literalmente incomparable (...) Con razón exclamaba Flaubert aludiendo al Quijote:'Comme on voit ces routes d'Espagne qui ne sont nulle part décrites": Q137. Así, somos realistas, y preferimos las cosas que caen sobre nosotros como panteras, sin trabajo alguno nuestro, y desalojan nuestra intimidad, a vivir de experiencias pensadas, civilizadas, que nos exigen esfuerzo, y sólo de este modo entran a construir "el edificio de nuestra personalidad".

De ahí que haya hombres más meditadores y otros más bien sensuales. Para éstos, todo es superficie mientras aquellos viven en la gran "profundidad". Los sentidos son el órgano principal del hombre sensual mientras el concepto es el medio propio del profundo, lo mismo que las impresiones son lo propio del mundo patente y las estructuras lo típico del latente.

\section{2. La vida como trama vital amorosa y el concierto nacional}

Cada cosa en su aislamiento es siempre una realidad pobre pero cuando se une a otras adquiere su plenitud, "se liberta y expansiona". Así, la realidad es la trama de las cosas, que se fecundan mutuamente y forman una estructura, desde el respeto, para darles consistencia y unión, formar los organismos y crear el mundo unido. Y, así, la Naturaleza, que es la máxima estructura, "es obra de amor": Q143. Entonces, la vida humana es una experiencia de amor, una trama amorosa, en la que cada cosa es el "centro del universo". Sólo, entonces, todas las cosas se respetan y avaloran, en la tranquilidad del orden, y se unen mutuamente, "sin invadirse unas a otras", con un "misterioso abrazo". El pensamiento es una obra de amor que da a cada uno lo suyo, aproxima los seres para que convivan y los distancia no sea que se confundan y aniquilen.

De ahí que todo el que ame honradamente, "profundamente la futura España", debe considerar el tema del pensamiento como "un menester nacional". Pues, aunque "la razón no puede, no tiene que aspirar a sustituir a la vida" (Q149), ayuda mucho, para organizarla, pensarla con claridad. Un pensamiento adecuado nos proporciona el hueco más apropiado para cada cosa en la vida, lo que es una gran ventaja, pues sólo lo que ha sido bien pensado cae bajo "nuestro poder" para darle el máximo de libertad y expansión. De ahí que, como aconseja Ortega: "al destronar la razón, cuidemos de ponerla en su lugar": Q153. 
Pero, entre nosotros, ha sido muy corriente una cultura de adanes. Vivir de simples impresiones, de lo primero que llega o se le ocurre a uno. A veces, eso proviene del carácter bronco y áspero de nuestros artistas y hombres de acción. Es una sicología de adanes. Así es Goya un Adán, un primer hombre sin edad, sin cultura, sin progresión, ente el clasicismo y el majismo, en perpetua lucha y en la frontera, siempre inseguro y vacilante, dinámico y caprichoso. "¿No es esta la historia de la cultura española? Todo genio español ha vuelto a partir del caos, como si nada hubiera sido antes": Q155. Pero toda cultura humana es seguridad, firmeza y claridad, lo fijo frente a lo volátil, lo claro frente a lo oscuro, "la luz como imperativo".

Además, el pensamiento "tiende a recoger en una fuerte integración de toda la herencia familiar": Q158. Necesitamos vivir de la primera impresión pero también de la meditación sosegada, de lo instintivo y lo profundo. No podemos ser puros españoles de costa reverberante, tenemos que poner paz entre nuestros ancestros. Ortega pide la paz: "No metáis en mis entrañas guerras civiles; no azucéis al ibero que va en mí con sus ásperas, hirsutas pasiones contra el blondo germano, meditativo y sentimental, que alienta en la zona crepuscular de mi alma. Yo aspiro a poner paz entre mis hombres interiores y los empujo hacia una colaboración": Q159.

La cultura es la pacífica posesión del mundo y de la vida, dominio de la situación, esclarecimiento del misterio. Así: "La vida es el texto eterno, la retama ardiendo al borde del camino donde Dios da sus voces. La cultura -arte, o ciencia, o política- es comentario, es aquel modo de la vida en que, refractándose esta dentro de sí misma, adquiere pulimento y ordenación": Q159160. Porque: "El hombre tiene una misión de claridad sobre la tierra": orientar y canalizar el torrente indócil de la vida. Para eso medita el sabio, tiembla el poeta y se esfuerza el político. Es una misión que la vida misma impone. En cada hombre se levanta un deseo inmenso de claridad. Como decía Goethe al morir: "Luz, más luz". Porque: "Claridad no es vida, pero es la plenitud de la vida".

$\mathrm{Y}$ haremos un mal servicio a nuestros semejantes si usamos el arte o la religión para oscurecer la vida, pues frustraríamos su misión esclarecedora, luciferina si se quiere, subraya Ortega, vital. En el verdadero arte, el artista lanza su mirada de águila "sobre su propio corazón y la existencia en derredor". Todo gran estilo "encierra un fulgor de mediodía y es serenidad vertida en las borrascas": Q165. Pero esto suele faltar en nuestras producciones castizas. Unos, consideran esto una gran virtud, Ortega lo ve como un gran defecto. Tenemos espontaneidad, fuego, coraje, vitalismo, pero nos falta sentido, claridad y poner en orden la casa. Así, el pensamiento nos da más de lo mismo y "no es tierra firme para el espíritu". En vez de suprimir el vitalismo hay que 
integrarlo mejor: "Yo no propongo ningún abandono, sino todo lo contrario: una integración".

\section{3. EI Quijote, el secreto español y la pregunta por España}

El Quijote es un ejemplo de todo esto. Ortega se pregunta: “_Habrá un libro más profundo que esta humilde novela de aire burlesco?": Q166-7. Schelling, Heine o Turgeniev ya hablaron al respecto. Para ellos, "era el Quijote una divina curiosidad: no era, como para nosotros, el problema de su destino": Q167. El Quijote cela el misterio español, como un gran interrogante en la llanada machega, "es como un guardián del secreto español, del equívoco de la cultura española (...) No existe libro alguno cuyo poder de alusiones simbólicas al sentido universal de la vida sea tan grande": Q167.

Pero, Cervantes no nos da pistas como suele hacerlo Shakespeare. Mantiene el enigma sobre el destino español, no alumbra su secreto, ni el "problema de su propia intimidad", ni su misión en la historia. Pero aún así, Ortega no se rinde: "Es, por lo menos, dudoso que haya otros libros españoles verdaderamente profundos. Razón de más para que concentremos en el Quijote la magna pregunta: Dios mío, ¿qué es España? (...) ¿qué es esta España, este promontorio espiritual de Europa, esta como proa del alma continental?": Q168.

Es necesario "aguzar nuestra sensibilidad para el problema de la cultura española, es decir, sentir a España como una contradicción”: Q170. Es necesario ir al fondo de nuestra conciencia étnica, revisar "todos los supuestos nacionales sin aceptar supersticiosamente ninguno". Un pueblo es siempre un ensayo de un nuevo modo de vivir, de "una nueva sensibilidad". De ahí que no sea tan fácil encontrar al verdadero español. Cuando un pueblo desarrolla plenamente sus posibilidades, esa nueva sensibilidad produce nuevo arte, nuevas instituciones, nueva ciencia, nueva literatura, "nuevos sentimientos y nueva religión".

Pero cuando esa sensibilidad se malogra fracasa todo, pues el nuevo estilo de vida de este pueblo no lo organiza ni mira a su entorno. Cada día es, ese pueblo, menos lo que tiene que ser. "Como este es el caso de España, tiene que parecernos perverso un patriotismo sin perspectiva, sin jerarquías, que acepta como español cuanto ha tenido a bien producirse en nuestras tierras, confundiendo las más ineptas degeneraciones con lo que es a España esencial": Q172.

Así, después de varios siglos de descarriado vagar, se nos propone seguir esa tradición, como si fuera la tradición, que "ha consistido precisamente en 
el aniquilamiento progresivo de la posibilidad España". Por eso, hay que ir contra la tradición, más allá de ella, pues España es una gran promesa que nunca ha sido cumplida. Lo que suele llamarse España no es la sustancia española profunda ni el temblor patriótico íntimo español, no es nada de eso, sino "justamente el fracaso de eso". Hay que purificar las esencias tradicionales para encontrar, el tesoro escondido, la perla preciosa de "la España que pudo ser".

Quien quiera encontrar hoy la verdadera España, ha de cantar "a la inversa la leyenda de la historia de España" (como los viejos marinos ante los cantos de sirena para librarse de ellas), y encontrar así la media docena de lugares claves donde el corazón de nuestro pueblo "da sus puros e intensos latidos". "Una de estas experiencias esenciales es Cervantes, acaso la mayor. He aquí una plenitud española": Q173. Si conociéramos bien el estilo de Cervantes, el sentido de su filosofía, su ciencia, su política, su moral, y su "inquebrantable solidaridad", tendríamos las claves profundas de la nueva España. "Entonces, si hay entre nosotros coraje y genio, cabría hacer con toda pureza el nuevo ensayo español".

Mientras tanto, hemos de contentarnos con vagas indicaciones, "más fervorosas que exactas", guardando las distancias, del gran novelista, para no decir nada extravagante o poco delicado como hizo el más famoso maestro de la literatura española, M. Pelayo, cuando afirmó que Cervantes era sólo el "buen sentido". Él era infinitamente más profundo que todo eso: Es la inverosimilitud en el Persiles, y la verosimilitud en Rinconete y Cortadillo. Es la fidelidad a sí mismo, que es el hombre verdadero, y a la ciencia del amor que es "la ciencia de las ciencias".

Así, el Quijote es, como el Escorial, el buque insignia de la vida y la cultura española. Y como éste es nuestra "gran piedra lírica" y "lósica" es, también, el palacio natural del Quijote (F. Rielo), pues es "Don Quijote rostro de castillo y "melancolía por el corazón", por eso Ortega hace estas MQ. en su propio ámbito. Los dos son un monumento al esfuerzo, al coraje, a la furia española, a la aventura y la hazaña, a unos hombres que, por encima de todo,"sólo queremos ser grandes", y de los que Nietzsche decía: "¡Los españoles! ¡Los españoles! ¡He ahí hombres que han querido ser demasiado!"”. Por lo demás, aquí España es llamada a resurrección pues la primavera del Escorial, ese "sepulcro inmenso", llena el cielo de "nubes de gloria y de triunfo" que "parece el escenario dispuesto para una resurrección"?. Para Ortega,

8 ID., Meditación del Escorial, O. C. II, 557.

9 ID., Muerte y Resurrección, O. C. II, 150. 
organizar 'la alegría española' lleva a que las torres de los pueblos "suenen siempre a campanas de Resurrección”.

Finalmente, Ortega recuerda que solía asegurar $\mathrm{H}$. Cohen, que las revoluciones son el tiempo de la Ética experimental. En ellas se intentan nuevas soluciones al grave problema de la justicia, el más humano de todos, que elevó hasta la incandescencia el corazón reseco de Alonso Quijano el Bueno. "Yo no pido a los jóvenes sino que al modo del santo orate manchego vengan a hablar entre los cabreros de este problema cruel, del tuyo y el mío"10.

Por eso mismo, es necesario reavivar entre nosotros el quijotismo, la sensibilidad del Quijote. Pues: "Quijotesca llamo a la sensibilidad para acontecimientos ideales, para las realidades abstractas, para las cosas transcendentales que ocurren en el seno de los valores eternos. Y lo que para Don Quijote era la justicia distributiva, era para Costa la decadencia de España"11.

\subsection{La novela del Quijote entre la comedia y la tragedia. El realismo de Cervantes}

El Quijote es como una novela contemporánea, de enorme sensibilidad, y el hombre es su tema fundamental. Pues, de uno u otro modo, "es siempre el hombre el tema esencial del arte": Q182. Es el gran tema del arte y la literatura que toman amplias vistas "sobre las vertientes cardinales de lo humano", ambas nos traen siempre "una confesión general de la intimidad humana" (Q230), y cada época histórica es "una interpretación radical del hombre". Por la experiencia del lirismo vemos que la intimidad del hombre varía a lo largo de los siglos, pues todo arte es antropología: "Dime lo que del hombre sientes y decirte he qué arte tienes".

En ese sentido, la novela no es épica, que es ya pasado legendario, sino todo lo contrario, es la pura actualidad, en su dimensión poética, contada por el autor: Q198. Esa realidad es muy indócil y diversa, con su rostro bueno y malo. No es la belleza de las cosas esenciales y prístinas imprescindibles, heroicas y hieráticas, que son de una vez para siempre, sino la de una realidad "sucedánea y decaída" que vive de la ilusión de las apariencias. Ahora bien, la épica en su huída es un fermento de gran energía que da lugar a la literatura de imaginación, con gran agilidad y poder plástico, que trasforma lo consabi-

10 ID., Los problemas nacionales y la juventud, O. C. X,117.

11 ID., La herencia viva de Costa, O. C. X,173. 
do en una "historia maravillosa". Su constitución tiene sólo un artículo: $\mathrm{Se}$ permite la aventura: Q202.

Es el realismo mágico, donde la historia es la mejor novela, que prolonga en la humanidad el influjo bienhechor de la épica. Los libros de caballerías fueron el último retoño del viejo tronco épico, perdida ya la fe en él. Ahora bien, el libro de imaginación narra, la novela describe. Se narra lo que pasó y se describe lo que ahora pasa, la realidad actual, de ahí que el diálogo es fundamental, y nos envuelve en el tema. De lo contrario, la novela es pura lata, cuenta lo que ya no interesa, nos quita la soledad y no nos da compañía.

La aventura "quiebra como un cristal la opresora, insistente la realidad" y crea un nuevo mundo imaginario, inverosímil, inventado, irreal, que permite escapar al peso grave de la vida y ver la realidad como patraña: Q207. Así, Cervantes nos saca de la realidad inerte:"quiso la inverosimilitud como tal inverosimilitud" que arrastra "el alma de don Quijote, ingrávida como un vilano". Y toda la vida es un retablo de maese Pedro.

Por lo demás, Cervantes une el mundo real y el poético: D. Quijote que es "real" quiere realmente las aventuras. Si se nos dice que don Q., pertenece plenamente a la realidad no nos enojaremos, pero incluiremos en esa realidad su "voluntad de aventura". Pues esa es "la naturaleza del hombre", donde lo real nutre lo poético para "elevar a una potencia estética más alta la aventura". Y aunque, a veces, lo posible "queda infartado en lo real como la aventura en el verismo de Cervantes", don Quijote "goza de una indubitable existencia": Q215-4.

En el Renacimiento surge el mundo subjetivo, el yo moderno, el me ipsum, la persona humana libre, y, de ahí, como flor de la nueva cultura, nace el Quijote. De la antigua épica aún se salva la aventura pero sometida a una gran ironía. De lo real, de lo actual mana, también, la sustancia poética "como agresión al orbe cristalino de lo ideal": Q216. Así surgen los gigantes de los molinos de viento. La realidad es un despertador del espíritu, como alusión nos impulsa, pero el realismo es también la caída en la pura materia.

Lo poético de la realidad es la realidad misma, no esta o aquella realidad. En este sentido, la realidad poética verdadera es su simple "estar ahí", su alusión a la ilusión, su impulso hacia la cultura crea un doble de la objetividad primaria que llamamos realidad, mientras que la comedia nace de un deseo de imitarla para burlarse de ella. Así, cuando la "idea" triunfa, la materialidad queda suplantada y "vivimos alucinados" y cuando ésta se impone "vivimos desilusionados".

Así, pues la realidad puede y debe ser, como en Leonardo, un "despertador del espíritu", pero el "realismo" es su desmoronamiento, no de la realidad, como tal, sino la pérdida del sentido claro y noble de una materia que, 
ahora, se "basta así misma", y se presenta como: "la bárbara, brutal, muda, insignificante realidad de la cosas": Q222. Cervantes no inventa el realismo sino que propicia su "expansión clásica".

El realismo es como un mimo, una imitación de la realidad que "imita para burlarse", con una intención cómica que da a la realidad nuevo valor estético. Así, pues, la novela desde que nace lleva dentro de sí, el aguijón cómico. Y: "La crítica, la zumba, no es un ornamento in-esencial del Quijote, sino que forma la textura misma del género, tal vez de todo realismo": Q225.

Ahora bien, las aventuras podrán ser vahos de un cerebro en fermentación, pero el esfuerzo, "la voluntad de aventura es real y verdadera". Pues, la aventura es una dislocación del orden material, "una irrealidad", porque "la querencia es real, pero lo querido es irreal". Aquí tenemos un hombre que quiere cambiar la realidad. No está contento con ella y quiere darle un curso distinto al que la tradición y los instintos suelen darle. A estos hombres los llamamos héroes.

\subsection{El héroe humano en el Quijote y España}

El héroe quiere ser él mismo sin que la circunstancia le apabulle. "Y este querer ser él mismo, es la heroicidad": Q227. Es un acto de la voluntad, por el que se hace uno mismo mientras resiste a la herencia, a los usos del presente y al orden antepasado. Esa es la máxima originalidad, la autenticidad. Es "una perpetua resistencia a lo habitual y consueto". Y así, el heroísmo es un perenne dolor trágico, pues quiere lo que no es, que se sitúa entre lo poético y lo teológico.

Así, el héroe en directo es lo trágico y en oblicuo lo cómico. Está como entre el bien y el mal, es como el orden del cosmos y su causa, lo divino y fatal, etc. El héroe se empeña en lo imposible, y, por eso, el villano piensa que todo héroe es un poco orate. Ese querer lo imposible, la aventura, lo irreal, crea lo trágico, mientras el villano vegeta feliz en su ser natural. Así, pues, lo trágico no viene de la fatalidad sino del empeño de héroe en cumplir su destino.

Todos llevamos dentro un "muñón de héroe" rodeado de "una caterva de instintos plebeyos". El héroe es ambicioso: quiere cambiar el mundo. Pero el instinto de inercia no lo puede tolerar y procura vengarse enviando, contra él, el realismo que trata de reducir su vida a una comedia y robarle su dignidad. El instinto plebeyo presiona al héroe para que se avenga a ser como los demás y su vida sea "como son las cosas". De ahí que "de lo sublime a lo ridículo no hay más que un paso". Al plebeyo le enfurece que el héroe pretenda "no ser como los demás" ni acepte las cosas como son, no respete lo casti- 
zo, lo de siempre, los hábitos sacrosantos de nuestros padres, la inercia eterna, y ensaye "nuevo arte, nueva ciencia, nueva política".

Pero como el héroe intenta ser lo que todavía, de hecho, no es, tiene medio cuerpo fuera de la realidad, y con tirarle un poco de los pies, fácilmente se consigue volverle a ella y así se le ridiculiza: Q237-8. El instinto de conservación no tolera más al héroe y se venga enviando contra él al realismo que lo envuelve en la comedia. Pero el héroe anticipa el futuro y la utopía, que, aunque todavía no es, él sí quiere que sea. Ese es el camino de lo cómico y ridículo a lo sublime. Todo esto pasa en el Quijote que está, por "el canto de un duro", entre la tragedia y la comedia. "La gente ríe", y: "La novela es tragicomedia": Q240.

Algunos conservadores creyeron que el Quijote era una pura comedia, porque a todo buen burgués le repugna lo sublime, reduce todo a comedia y "se revuelca en lo vulgar". Y por eso, el pensamiento del, mal llamado, patriotismo español no ha sido todavía capaz de estudiar los hechos españoles verdaderamente grandes. Todo el entusiasmo se gasta en alabanzas estériles de cosas poco loables, y no se emplea en lo que hace falta.

Por otra parte, la línea superior de la novela es una tragedia. La novela es tragicomedia. El Sócrates de Platón cree que un mismo autor es el de la tragedia y la comedia. Así don Quijote será el héroe y el orate. Y, por eso, toda novela lleva dentro de sí El Quijote. Así lo proclama Flaubert que se lo sabía de memoria desde niño, antes de aprender a leer. Para él, la literatura actual no tiene auténticos críticos, porque la novela actual tampoco tiene tensión, como no la tiene la vida, mientras "la tensión del Quijote promete no gastarse nunca": Q242.

El siglo XIX niega todo heroísmo, y es de un realismo feroz que Flaubert odiaba de corazón. "Hechos, sólo hechos" clama un personaje de Dickens. Es una realidad tan feroz que no consiente ningún ideal ni siquiera de ella misma. Pero, además, nuestro siglo XX se ha revolcado en el pesimismo y la amargura, y es como una bocanada de rencor.

Para rematarlo del todo, las propias ciencias han sido deterministas, carentes de libertad verdadera. Para ellas, vivir es adaptarse. Así: "Darwin barre los héroes de sobre el haz de la tierra": Q244. Nuestras acciones son meras reacciones, no hay libertad, ni originalidad alguna posible. Zola insiste en el positivismo: el medio dirige al hombre y es único protagonista.

Entonces no hay verdad estética ni belleza verdadera, todo es física y determinismo. La vida, según Flaubert, no tiene ya interés alguno y la novela aspira a ser pura fisiología. Pero en Ortega la vida es libertad, invención, faena poética y voluntad de aventura. 


\section{LA ESPAÑA DE ORTEGA}

\section{Introducción}

Quizá hoy convenga, escuchar, la recomendación de Fichte: Dejad que yazcan diseminados y confusos los componentes de nuestra vida humana y "los lazos totalmente rotos de nuestra unidad nacional" para que un día sean llamados a resurrección. El espíritu actuará sobre "los miembros mortecinos de nuestro cuerpo nacional y los unirá unos a otros de la manera que volverán a surgir con magnificencia en una vida nueva y transfigurada"12.

En lo que se refiere a España, ya en 1949, G. Santayana se temía que su verdadera alma "esté desintegrada en la actualidad", a lo que un sabio quijote agustino respondió: "España nunca estuvo integrada: cada español, incluido Santayana, es una España por sí mismo"13. Así que, como dice el refrán: menos lobos que la mitad son urces...

\section{1. La vida Nacional como proyecto común en un mundo en disolución}

Hoy nos encontramos ante un mundo que se disuelve ante nuestros ojos, como rocío mañanero, y es difícil saber cómo reparar nuestra situación, llamarla a cordura y vida. En nuestro tiempo ha entrado en crisis el individuo, la sociedad, el Estado, la revolución, el liberalismo y el socialismo y no sabemos qué hacer. Hoy, la idea de comunidad parece el único estímulo14. Si volvemos los ojos a los clásicos, veremos a Mommsen, escribir: La historia de toda nación, y sobre todo de la nación latina, es un vasto sistema de incorporación ${ }^{15}$.

O como diría Ortega: "Antes que nada es el Estado proyecto de un hacer y programa de colaboración. Se llama a las gentes para que juntas hagan algo.

12 J. G. FICHTE, Discursos a la nación alemana. Barcelona 1984, 92. En adelante D.

13 D. RuBio, La filosofía del Quijote. Prefacio de L. Cilleruelo. Valladolid 1953, 24. En esta obra y en su estudio sobre el alma mística de España, el P. Rubio defiende que el cristianismo es la clave del alma española con su mística de la inmortalidad, que lucha por la verdad y la justicia, aún en la adversidad. F. Rielo cree que "Cervantes pasó a la novela la mística española": F. RIELO, Teoría del Quijote. Su mística hispánica. Madrid 1982, 176,59,62-67. En lucha por la justicia: Ib., 16-7,129,145.

14 ID., Reivindicación de la libertad de pensamiento y otros escritos políticos. M. 1986, 63. En adelante RL.

15 J. ORTEGA Y GASSET, España Invertebrada. Bosquejo de algunos pensamientos históricos. Madrid 1934, 4a , 6-7. En adelante E. Quizá pueda preguntarse por el sentido de reunir a Fichte y Ortega. A. Ciria afirma lo siguiente: "Fichte no nos ha legado una doctri- 
El Estado no es consanguinidad, ni unidad lingüística, ni unidad territorial, ni contigüidad de habitación. No es nada material, inerte, dado y limitado. Es un puro dinamismo, la voluntad de hacer algo en común"16.

Cuando este impulso de gran empresa falta, la sociedad se desintegra, no sabe a qué atenerse, se encuentra en un estado neutro "en que al mismo tiempo no se quiere lo que se quiere e igualmente se quiere lo que no se quiere": RL135. Pues la: 'Nación', "en el sentido que este vocablo emite en Occidente desde hace más de un siglo, significa la 'unión hipostática' del Poder público y la colectividad por él regida": R183.

Como diría Renan, la nación es un "plebiscito diario". La nación está siempre "haciéndose o deshaciéndose", en su sistema de preferencias, normas, en sus resortes vitales e ideologías. No puede vivir sin "una gran empresa" que la una. La vida llama a la nobleza de lo sublime y la "integridad interior": ES61. La educación es el camino17, la concordia social, su finalidad.

Esto nos quiere advertir que una nación no es, simplemente, un núcleo geográfico, lingüístico o sanguíneo, ni siquiera la invasión de un núcleo sobre el resto del territorio, sino más bien "la organización de muchas unidades sociales preexistentes en una nueva estructura". Se trata de un equilibrio integrador de cada una de las partes.

A su vez, la descomposición de un pueblo: "La historia de la decadencia de una nación es la historia de una vasta desintegración". Por tanto, la unidad de una nación no es una coexistencia pacífica inerte, sino "un sistema dinámico" sostenido activamente. Sin la participación de todos, la nación se disuelve y la unidad se resquebraja.

El simple espacio histórico común no genera una nación, sino la efectiva y prolongada convivencia: "convivencia y sociedad son términos equipolentes. Sociedad es lo que se produce automáticamente por el simple hecho de la

\footnotetext{
na trascendental de la pedagogía en una elaboración terminada, pero es fácil emplazarle en la historia del pensamiento pedagógico como seguidor de Pestalozzi y como maestro de Krause. Sería tema de un estudio específico determinar el ascendiente fichteano sobre los fundamentos pedagógicos de la Institución Libre de Enseñanza":A. CIRIA, Estudio preliminar, traducción y notas de J. G. FICHTE, Sobre la esencia del sabio y sus manifestaciones en el dominio de la libertad. M. 1998, XLIII. En adelante ES. Es conocida la relación de Ortega con el método de Pestalozzi, con el krausismo español y la ILE. Y que: "En el plano de la educación no se ha hecho nada en la España contemporánea comparable, ni de lejos, con lo que hizo la Institución": J. L. L. ARANGUREN, en A. JIMÉNEZ G., El krausismo y la Institución Libre de Enseñanza. Madrid 1992, 2a 150.

16 J. ORTEGA Y GASSET, La rebelión de las masas. Madrid 1981, 3ª 176-7. En adelante $\mathrm{R}$.

17 "Educar (es)(...) hacerse por sí mismo maestro y auto-dominador absoluto de toda su fuerza": ES, 121.
} 
convivencia. De suyo e ineluctablemente segrega ésta costumbres, usos, lengua, derecho, poder público": R16.

$\mathrm{El}$ poder creador nacional es un quid divinum y misterioso que a todos nos compete y a todos nos obliga. En todo ese proceso, la fuerza tiene un papel secundario, aunque también algunas veces deberá reducir el egoísmo, pero lo realmente importante es: un proyecto sugestivo de vida en común. Una nación es una comunidad de propósitos, anhelos y utilidades comunes, no se trata, simplemente de estar juntos, de ser de un mismo lugar, tener un mismo idioma o idéntica sangre sino que se trata de hacer algo juntos.

Cuando este plan común falta, la unidad del pueblo se diluye. Así ha ocurrido que: "Con los pueblos de Centro y Sudamérica tiene España un pasado común, raza común, lengua común, y, sin embargo, no forma con ellos una nación. ¿Por qué? Falta sólo una cosa, que por lo visto, es esencial: el futuro común": R188. España no supo ofrecer un programa de porvenir colectivo, y por eso el plebiscito de proyecto común resultó adverso. Entonces, de poco sirven las memorias y los archivos del pasado. Si se quiere hacer algo, juntos, hay que activarlo, ponerlo en marcha, pues las palabras se las lleva el viento.

Pero un pueblo no busca simplemente la utilidad inmediata, también son importantes la fidelidad y el apoyo mutuo, el honor, la honestidad, la defensa de la calidad histórica del pueblo, su respeto y promoción, su moralidad y su vitalidad nacional. Se trata de un equilibrio de fuerzas que a todos revitaliza, confiere libertad y dignidad propia a cada individuo y a cada grupo, no de una homogeneidad inerte. Pues, la libertad y el pluralismo, entraña de la democracia, son dos fuerzas recíprocas que mutuamente se impulsan: R23. Este proceso permite la continuidad y la renovación, la aceptación del pasado y la construcción del futuro, de lo contrario nos haremos un pueblo de paralíticos o de epilépticos.

Para levantar una nación hay que contar con todos sus ciudadanos. Pero cada uno debe aprender a mandarse a sí mismo antes de mandar a los demás, a superar el propio egoísmo y la visión estrecha de los propios intereses antes de llamar a los otros a pensar en grande. Se trata de un proyecto imaginativo y magnánimo que entre todos los grupos hay que fundar y cuidar unidos.

Un pueblo desordenado que no intenta grandes cosas ni piensa en grande, nunca será una auténtica nación, se quedará en pura masa. Como: "El nacionalismo es siempre un impulso de dirección opuesta al principio nacionalizador. Es exclusivista, mientras éste es inclusivista. En épocas de consolidación tiene, sin embargo, un valor positivo y es una alta norma": R195.

Como decía Renan, construir una nación supone: "Tener glorias comunes en el pasado, una voluntad común en el presente; haber hecho juntos grandes cosas, querer hacer otras más; he aquí las condiciones esenciales para 
ser un pueblo... En el pasado, una herencia de glorias y remordimientos; en el porvenir, un mismo programa que realizar... La existencia de un nación es un plebiscito cotidiano": R185.

\subsubsection{El vicio del Particularismo y la desintegración Nacional}

Cuando ese acuerdo común y esa voluntad de convivencia, cotidiana, se olvida, la Nación se desintegra, cada uno va a lo suyo, se aísla de los otros, se rompe el pacto de convivencia y el respeto a los demás. A esto le llama Ortega, particularismo. "La esencia del particularismo es que cada grupo deja de sentirse a sí mismo como parte, y, en consecuencia, deja de compartir los sentimientos de los demás": E43.

Entonces, ya no importan las esperanzas comunes ni las necesidades de los otros, cada uno va a lo suyo y es característica de esta situación "la hipersensibilidad para los propios males" y la insensibilidad y alergia al dolor ajeno. Problemas y dificultades que en otros tiempos se compartían y se soportaban fácilmente, resultan intolerables "cuando el alma del grupo se ha desintegrado de la convivencia nacional".

Este problema es importante cuando se manifiesta con protestas y reivindicaciones, pero es todavía más alarmante cuando va fraguando en una voluntad inerte que se desentiende del interés general y se interna profundamente en la vida civil. Además, según Ortega: "cuando una sociedad se consume víctima del particularismo, puede afirmarse que el primero en mostrarse particularista fue precisamente el Poder central": E45. El propio poder ha sido el primero en romper la confianza mutua, el respeto a las normas y hábitos del bien común, de lo honesto y noble para el mejor proyecto político, científico y moral. Se sofoca la iniciativa y se persigue la innovación. Se promueve la suspicacia, los atajos de vía estrecha, la acritud y la sordidez.

La autoridad suprema e incluso, a veces, la Iglesia, ya no promueven ideales nacionales, de todos, sino que cada grupo se defiende a sí mismo y busca su propio interés sin mirar a los demás. Hoy se glorifica la mediocridad y se aísla a los mejores. Y, "esta preferencia reiterada de lo ruin a lo selecto, es el síntoma más evidente de que no se quiere en verdad hacer nada, emprender nada, crear nada que perviva luego por sí mismo. Cuando se tiene el corazón lleno de un alto empeño, se acaba siempre por buscar los hombres capaces de ejecutarlo": E48.

Así, se va a triturar el pacto de convivencia, los proyectos de futuro. Entonces, sólo queda la sombra de un pueblo que un día fue grande pero que se ha difuminado y perdido. Sin fidelidad a la gente todo es pura mercadería. En 
cambio, el querer ético: "Termina en nosotros el vaivén de la contratación, deja de ser nuestro espíritu una pluralidad de individuos elementales cada cual con su pequeño afán egoísta que es preciso contentar"18.

De ahí que la grandeza moral sea una tarea decisiva en la construcción nacional. Pues siempre que vivimos con un corazón grande y buscamos plenitud: "Cuando todo nuestro ser quiere algo 'sin reservas, sin temores, integralmente' cumplimos con nuestro deber, porque es el mayor deber de fidelidad a nosotros mismos. Una sociedad donde cada individuo tuviera la potencia de ser fiel a sí sería una sociedad perfecta": NAV80.

\subsubsection{Los diversos grupos sociales y la construcción nacional}

La unificación de un pueblo necesita de los distintos grupos sociales que lo forman, "como son el mundo militar, el mundo político, el mundo industrial, el mundo científico y artístico, el mundo obrero, etc". Todos esos mundos son necesarios y se precisan mutuamente. Pero, con frecuencia, la inercia y la vida fácil los cierra, unos a otros y reduce su horizonte común.

Así el grupo pierde conciencia de su integración social, de sus límites propios, de la idea de convivencia y cooperación social y se encierra en sus preocupaciones exclusivistas. Por el contrario, en los momentos difíciles, todos miran a los demás, la sociedad se compacta y vibra ante el destino común. La vida de cada individuo y de cada grupo queda "multiplicada por la de los demás", todo el potencial activo se aprovecha y se pueden pensar grandes cosas. Es, pues, necesario que cada grupo conozca y tenga en cuenta la vida de los otros, de lo contrario la, así, mal llamada nación se convierte en una serie de compartimentos estancos.

A veces se dice que los políticos no se ocupan de los problemas de la gente, pero tampoco ésta parece preocuparse de aquellos. Como dice Sloterdijk: "Probablemente, el general menear la cabeza en alusión a las deficiencias del personal político oculta un descontento global que aún no ha tomado forma: apostaría directamente a que se trata de los estados aurorales de una toma de conciencia de alcance mundial sobre insuficiencias antropológicas. Pues lo que salta a la vista de los intranquilos contemporáneos con respecto a tantos políticos 'el hecho de que raramente estén a la altura de los retos globales' igualmente rige, con más razón, para los que no son políticos. Se debería examinar si la censura crónica a la clase política no será la proyección de

18 J. ORTEGA Y GASSET, Notas de andar y ver. Madrid 1975, 11ª, 79. En adelante NAV. 
un malestar general de la cultura mundial, sólo que cristalizado ante la prominencia política"19.

De hecho, con frecuencia, los grupos se preocupan muy poco unos de otros, de modo que cada uno va a su aire: "Vive cada gremio herméticamente cerrado dentro de sí (...) Polarizado cada cual en sus tópicos gremiales, no tiene ni noticia de los que rigen el alma del grupo vecino": E57-8. Los valores de cada grupo no se contagian a los otros ni tienen repercusión, en los demás, sus anhelos. Es difícil imaginar un conglomerado humano con menos unidad. Cada uno se mueve, en la sociedad, como Pedro por su casa, como un hijo de papá al que todo se le tolera. De hecho hoy: "El inmoralismo ha llegado a ser de una baratura extrema, y cualquiera alardea de ejercitarlo": R198. Se pretende tener todos los derechos sin ninguna obligación, y esa es una vida inmoral y amoral.

El caso del grupo del Ejército es particularmente significativo en nuestra historia reciente y, por suerte, ya pasada. Así, en el caso de España, se trata de un grupo que se había desmoralizado tras las pérdidas coloniales aunque nunca se le exigieron responsabilidades, pero hasta el moderado Costa pidió que "se sellase el arca del Cid", es decir, que nunca más se plantease horizonte alguno de guerra ni de recurso al Ejército.

Entonces, las clases militares se sintieron preteridas, fermentó en el grupo armado el resentimiento y la antipatía, con una cerrazón cada vez más hermética, hacia las otras clases sociales, sin intercambio de vida. "En los individuos de nuestro Ejército germinó una funesta suspicacia hacia políticos, intelectuales, obreros (la lista podría seguir y aún elevarse mucho)".

$\mathrm{Al}$ vivir en esta tesitura, el grupo militar era como una escopeta cargada sin blanco al que disparar. Desvinculado de las otras clases sociales sentía la tentación de caer sobre la nación y tratar de conquistarla. Eso que pasó en el ejército ocurría en los otros grupos sociales. Como sabemos hoy, por suerte, el sentido solidario de la clase militar se ha elevado notablemente como ha demostrado en las misiones de paz y solidaridad que viene realizando.

Cuando ese sentido solidario falla, perdido el sentido común, se sufre "el espejismo de creerse solo y todo". Evaporada la fe en el proyecto nacional, y la sensibilidad hacia los demás, se piensa que la propia misión es conquistar el poder e "imponer directamente la propia voluntad", mediante pronunciamientos y acción directa, sin atenerse a derecho ni a norma alguna, ni vigencia colectiva que se da por desaparecida. De este modo, la masa se cree que "El Estado soy yo", ya que se ha des-socializado y no cree en la convivencia.

19 P. SLOTERDIJK, En el mismo barco. Ensayo sobre la hiperpolítica. Trad. M. Fontán, Madrid 2000, 2 $2^{\mathrm{a}}, 72$. 
Se trata de "la violencia como norma" y de la ausencia de todo diálogo. Así el servicio al Estado o el deseo de conquistar el Estado justifica la violencia. "Hoy es ya la violencia la retórica del tiempo; los retóricos, los inanes, la hacen suya": R135 (Subrayado nuestro).

\subsubsection{La desintegración nacional y la acción directa}

La desintegración nacional o particularismo "se presenta siempre que en una clase o gremio, por una u otra causa, se produce la ilusión intelectual de creer que las demás clases no existen como auténticas realidades sociales o, cuando menos, que no merecen existir. Dicho aún más simplemente: particularismo es aquel estado de espíritu en que creemos no tener por qué contar con los demás": E66.

Unas veces por desprecio del prójimo y otras por excesiva confianza en nosotros mismos, se pierde la noción de los límites y se cree uno independiente de todos. Nos olvidamos de la dependencia y relación que tenemos con los demás. "Ahora bien: una nación es a la postre una ingente comunidad de individuos y grupos que cuentan unos con otros":E67. En una situación normal, cuando alguien quiere algo, trata de conseguirlo de acuerdo con los demás. Entonces intenta convencer al prójimo y establecer una nueva legalidad. Tiene para ello las instituciones y los grupos que son resortes de comprensión y de solidaridad.

Pero, para el que no es demócrata, este camino es una gran humillación, porque para él los demás no son nadie y uno no quiere contar con don nadie. Así, critica a los políticos y a la política, pero al hombre experto no se le escapa el tema, y se le hace muy sospechosa esa repugnancia a lo político. Pues, parece que fueran los políticos los únicos que no hacen sus deberes ni tienen cualidades para cumplir sus graves obligaciones. "Diríase que nuestra aristocracia, nuestra Universidad, nuestra industria, nuestro Ejército, nuestra ingeniería, son gremios maravillosamente bien dotados que encuentran siempre anuladas sus virtudes y talentos por la intervención fatal de los políticos":E69.

Todo esto es una hipocresía y una gran insinceridad, pues cada grupo no puede escudarse en otros. Los vicios de los políticos son los de la sociedad e incluso, a veces, son "menos malos que el resto". Y aunque existan otras causas, "la causa decisiva de la repugnancia que las demás clases sociales sienten hacia el gremio político me parece ser que éste simboliza la necesidad en que está toda clase de contar con las demás":E70.

$\mathrm{Y}$ es que parece que la única actividad pública que satisface hoy plenamente a cada clase social, "es la imposición inmediata de su señera voluntad". 
Así, los obreros se consideraron a sí mismos como la única clase social verdadera dueña de la realidad pública. El parlamentarismo y el diálogo les parece, a algunos de ellos, actividad propia de usurpadores.

Por su parte, los militares, incluso los de temple heroico, vivieron una época que padecían tal cerrazón mental y tal idealismo ingenuo que consideraban innecesario convencer a los demás de las propias opiniones o luchar por conseguir sus deseos. Creían que todo el mundo pensaba, en secreto, lo que ellos creían bueno, y que bastaría con pronunciar una frase para producir el efecto mágico apetecido. "No iban, pues, a luchar, sino a tomar posesión del Poder público".

En general, nos encontramos hoy, advertía Ortega, con una gran disociación nacional, pero sin gana alguna de luchar por una nueva integración. Así se cree que todo será fácil y que los demás se avendrán sin rechistar a los propios intereses. Se piensa que la partida está ganada sin discusión ni problema alguno. De ahí, que la acción directa es "la táctica del victorioso, no la del luchador". La civilización ha intentado hacer de la fuerza la última razón, pero la acción directa la ha tomado por razón primera. Esta "es la Carta Magna de la barbarie": R100.

La acción directa es la incultura, la invasión de los nuevos bárbaros, es lo contrario del liberalismo, la tolerancia y respeto al enemigo, fuerte o débil. “ ¡Convivir con el enemigo! ¡Gobernar con la oposición! ¿No empieza a ser ya incompatible semejante ternura?" Nada acusa con mayor claridad la fisiognomía del presente, como el hecho de que vayan siendo tan pocos los países donde existe la oposición. En casi todos, una masa homogénea pesa sobre el Poder público y aplasta, aniquila todo grupo opositor. La masa "¿quién lo diría al ver su aspecto compacto y multitudinario?" no desea la convivencia. "Odia a muerte lo que no es ella".

En España, tanto los obreros y republicanos, de 1917, como D. Antonio Maura, se pronuncian por lo suyo y para los suyos. Los demás no existían, ni había que atraerlos o corregirlos sino "excluirlos, eliminarlos, distanciarlos, trazando una mágica línea entre los buenos y los malos. De aquí el famoso 'Nosotros somos nosotros"'. Y aunque, es bien sabido que las grandes cosas no se hacen nunca con exclusiones, pues son obra de todos, hoy en el periódico, en el sermón y en el mitin se habla sólo ya al parroquiano convencido, y los demás son infieles. Y, como decía Ortega, en su tiempo: hasta los báculos se vuelven lanzas.

Sobra, pues, soberbia pimpante y falta cordialidad combatiente, hay que excluir la exclusión, como decía Renan. Porque hoy cualquiera tiene fuerza para deshacer: "el militar, el obrero, este o el otro político, este o el otro grupo de periódicos, pero nadie tiene fuerza para hacer, ni siquiera para asegurar sus 
propios derechos": E80. Hay que aunar fuerzas para sacar adelante la nación, superar el aislamiento y los intereses corporativos, y hacernos un pueblo nuevo.

\subsubsection{Hombres nuevos para un pueblo nuevo}

La política es una relación, exigente, entre autoridades y pueblo, entre la gran masa popular y sus minorías dirigentes. No basta con que alguien tenga buenas ideas, hace falta que éstas sean comunicadas, compartidas y encarnadas por la mayoría. Eso supone generosidad en el pueblo y en los dirigentes, de lo contrario solamente triunfarán las propuestas más vulgares.

Sin el entusiasmo razonable del pueblo, los dirigentes no podrán cumplir su tarea, porque hoy la autoridad ha de contar con una auténtica opinión pública y animar a que la gente se pronuncie. "Sin opiniones la vida de los hombres carecería de arquitectura, de organicidad": R147.

Pero, en ciertas épocas, el alma popular parece perder el sentido y anularse: se hace envidiosa, petulante, sórdida, atrofia su capacidad de descubrir grandes hombres y de crear mitos sociales. Surge, entonces, "en la muchedumbre un plebeyo resentimiento contra toda posible excelencia, y luego de haber negado a los hombres mejores todo fervor y social consagración, se vuelve a ellos y les dice: 'No hay hombres": E42.

Como dice Slöterdijk, hoy los políticos se encuentran, como por arte de magia, con una tarea y un programa casi imposible: "convivir con aquellos con los que convivir resulta difícil", con un deseo de relacionarse con los irrelacionables. A veces, parece que los pueblos padecieran como "una paranoia étnica y vecinal", se meten en "psicopatológicos callejones sin salida", restos de una "cultura agraria", de la "pandilla sin sustancia" o del "individualismo de apartamento", donde "las patologías de la pertenencia se vuelven epidémicas" y así, nuestros políticos, se ven, continuamente, obligados a convertirse en atletas de la convivencia, "almas de alta capacidad en el tema de la coexistencia"20.

Hoy, es preciso recordar que una nación es una ecuación respetuosa, un equilibrio delicado, entre el pueblo y sus dirigentes. Cuando este equilibrio se rompe, la nación se deshace, la sociedad se desintegra, "sobreviene el caos social" y la falta de vertebración auténtica. No se trata de un problema de formas políticas ni de moralidad pública sino de un tema más de fondo. Las formas políticas cambian, la inmoralidad pública se corrige, pero la desintegra-

20 Ib., 73-44, 90, 96-97. 
ción social es algo mucho más grave: La nación se descompone y se produce como una infección general del organismo social muy difícil de curar. "En suma: donde no hay una minoría que actúa sobre una masa colectiva, y una masa que sabe aceptar el influjo de una minoría, no hay sociedad, o se está muy cerca de que no la haya": E98.

Así, en los cuartos de banderas se creía entender más de política que los políticos. Todos los partidos han creído saber más que sus dirigentes. El público cree saber más que el escritor, el compositor o el crítico, las damas aburguesadas quieren imponer sus gustos u opiniones, los peores se vuelven contra los mejores, y la sospecha de que alguien pretende entender más que el público le pone a éste frenético. Así, la sociedad arrastra invertebrada su convivencia y las instituciones, heridas de muerte, anulan toda excelencia y viven sin mandamiento: R152.

Entonces, las masas de la burguesía, de la milicia o del proletariado quieren imponer su gobierno. Pero el fracaso repetido, de una propuesta tras otra, les hace descubrir que las cosas son más complicadas de lo que creían. Además, la vida ciudadana sufre la inseguridad pública, la economía se debilita, todo se vuelve angustioso y desesperante. Así se entra en razón y comienza un nuevo ciclo: "Cesa el rencor contra la minoría eminente. Se reconoce la necesidad de su intervención específica en la convivencia social”.

Tiene la historia, según Ortega, sus épocas Kitra y épocas Kali. Esta es un tiempo de confusión, de degeneración y desánimo, pero luego reaparece la esperanza, se recrea el mundo nuevo y alborea la época Kitra. Se ve que la sociedad tiene una cierta estructura, necesita organización y jerarquía, como el hombre cabeza y pies, la tierra norte y sur, y la pirámide cúspide y base, pero esto no quiere decir que haya ningún principio de linaje ni de sangre, ni ningún otro privilegio.

La convivencia social no es el resultado de una utopía idealista ajena a la realidad. La idea del deber ser ético o jurídico, de una sociedad, no puede suplantar al sentido común: "Toda recta sentencia sobre cómo deben ser la cosas presupone la devota observación de su realidad (...). Si sabemos mirarla, toda realidad nos enseñará su defecto y su norma, su pecado y su deber". El verdadero imperativo ético surge de la realidad: "llega a ser lo que eres", amonestaba Píndaro. Pero el “'señorito satisfecho' es la falta de autenticidad en casi todo su ser”: R124, nota. 


\subsubsection{Entre Masas y Minorías}

Hoy vivimos en un mundo de masas. Nuestro mundo está lleno de gente: las casas, los hoteles, el tren, los cafés. Las masas se han adelantado al primer puesto de la escena social: R48. Este fenómeno tiene un aspecto positivo, de mejora general de la vida humana, y otro negativo de desmoralización radical de las gentes.

La sociología vulgar identifica masa con plebe, y minoría selecta con la clase más elevada. Esto es totalmente falso. "Precisamente lo que acarrea la decadencia social es que las clases próceres han degenerado y se han convertido casi íntegramente en masa vulgar": E115. Así, la sociedad se desmoraliza. "Y esta es la pura verdad. Todo el mundo 'naciones, individuos', está desmoralizado. Durante una temporada, esta desmoralización divierte y hasta vagamente ilusiona (...) Pero la fiesta dura poco. Sin mandamientos que nos obliguen a vivir de un cierto modo, queda nuestra vida en pura disponibilidad. Esta es la horrible situación íntima en que se encuentran ya las juventudes mejores del mundo. De puro sentirse libres, exentas de trabas, se sienten vacías"21.

No hay que entender, pues, por masas, "las masas obreras". Con frecuencia, el hombre masa es hoy el hombre de ciencia, el hombre de actualidad sin sentido global del mundo. Se trata de un hombre cualificado que a la vez es un individuo sin "instancia superior". "Masa es "el hombre medio": R48. Masa es quien no se valora a sí mismo, vive sin decoro ni norma alguna, perdido en el caos total, sin ideal ni mandamiento, no sabe qué hacer con su vida, ni a qué carta quedarse, y no va a ninguna parte pues no sabe a dónde va.

Para Ortega es una "habitual bellaquería" pensar que por minoría selecta se entiende el petulante que se cree superior a los demás. Muy al contrario, la humanidad se divide en dos clases de criaturas: "Las que se exigen mucho y acumulan sobre sí mismas dificultades y deberes, y las que no se exigen nada especial, sino que para ellas vivir es ser en cada instante lo que ya son, sin esfuerzo de perfección sobre sí mismas, boyas que van a la deriva": R49.

La conducta humana nunca es pura imitación, pero sí hay una emulación de la vida ejemplar que nos lleva a "reformar verídicamente nuestra esencia", con entusiasmo por lo óptimo que vemos realizado en los demás. Este sentido de lo auténtico existe en cada familia y también en la sociedad, y no puede ser sustituido ni por la pura utilidad ni por la fuerza del poder.

21 R 153. Cf.: G. LIPOVETSKY, La era del vacío. Anagrama, Barcelona 2000, 21ª 
Lo propio del alma vulgar es afirmar, sin más ni más, su vulgaridad. Pero, la verdadera autoridad tiene su origen en la autenticidad de vida, y es para toda la sociedad manantial de perfección. De hecho, la vida humana, por lo general, se ha elevado positivamente en vitalidad y posibilidades. Toda auténtica nación produce un cierto número de hombres eminentes en el sentido intelectual, moral y vital. Y cada clase social genera también siempre un número adecuado de hombres egregios. Porque, una nación no puede vivir con un solo tipo de excelencia o virtud: "Hace falta, junto a los eminentes sabios y artistas, el militar ejemplar, el industrial perfecto, el obrero modelo y aún el genial hombre de mundo. Y tanto más que todo esto, necesita una nación de mujeres sublimes": E122-3. Si faltan esas personas, la nación cojeará y flaqueará en alguna de sus funciones importantes y puede que todo el pueblo resulte afectado. En todo caso, el desprecio de los mejores muestra la perversión de un pueblo.

Hay naciones que han tenido abundancia de hombres excelentes, otras han padecido una escasez atroz. En el caso de España, la desproporción ha sido inmensa. Aquí, todo lo ha hecho el pueblo, las personalidades auténticas han sido rarísimas. Se trata de una vida anónima que elude las grandes obras de orden "material o moral". Aquí, por no haber, no ha habido ni auténtico feudalismo ni sentido creativo y ha faltado señorío.

Se trata de un mundo decadente, enfermo y desvitalizado, sin ansia de libertad. Así, la unidad ha sido también falsa. Pues "la unidad sólo es definitivamente buena cuando unificaba grandes fuerzas preexistentes. Hay una unidad muerta, lograda merced a la falta de vigor de los elementos que son unificados": E146.

Aquí, como en otras naciones, con frecuencia, "la anormalidad ha sido lo normal", el abuso uso, y así la vida es muy escasa y los entusiasmos flacos. Es un defecto original, de principio y de matriz, como si nunca hubiésemos llegado, a una cierta "plenitud de los tiempos".

A veces, las naciones "mueren de satisfacción", no saben renovar sus deseos. Así el pueblo español dio sentido popular a otros países pero no les pudo ofrecer: disciplina superior, cultura vivaz, civilización progresiva. Ha faltado un poco de cabeza y quizá aún nos falta. Vivimos la algarabía de los chicos que "se han escapado de la escuela". El hombre parece dominar todas las cosas pero no se sostiene a sí mismo ni es "dueño de su vida".

La ausencia de los mejores crea ceguera en el pueblo para ver los hombres buenos, de modo que cuando surgen, "la 'masa' no sabe aprovecharlos, y a menudo los aniquila". Además, hay como una "deserción de las minorías directoras", es el reverso de la rebelión de las masas. Triunfa el ruralismo, el aldeanismo se impone. Participamos en la historia universal y tenemos buenos 
gobiernos pero no salimos de los atolladeros de siempre. "No podrá extrañar que hoy el mundo parezca vaciado de proyectos, anticipaciones e ideales. Nadie se preocupó de prevenirlos".

Con frecuencia, nos encontramos, hoy, con el "señorito satisfecho" que piensa que la vida es fácil, que sólo existen él y los suyos, y que, como el "niño mimado", puede imponer sus caprichos, su íntima barbarie por medio de la acción directa. El muchacho, el adolescente, infantil, es hoy el amo del mundo. Así, el "señorito satisfecho" realiza abiertamente su carácter verdadero: "Envilecimiento, encanallamiento, no es otra cosa que el modo de vida que le queda al que se ha negado a ser el que tiene que ser": R125, nota 1.

Hoy estamos ante tiempos nuevos. Ha mejorado mucho la vida económica del hombre medio. Pero es preciso decidirse. Las circunstancias son excelentes para intentar rehacerse, pues tenemos "la democracia liberal" y "la técnica". Pero, hay que curar sobre todo, y en primer lugar, los males que anidan en el alma del pueblo, sus defectos íntimos. Pues, "El hombre-masa es el hombre cuya vida carece de proyecto y va a la deriva. Por eso no construye nada, aunque sus posibilidades, sus poderes, sean enormes".

El odio de los mejores es el ejemplo más lamentable de perversión, raíz de todos los males. Así, las naciones, "no hacen sino deshacer, desarticular, desmoronar, triturar la estructura nacional": E166. Eso es lo que Rathenau llamaba "la invasión vertical de los bárbaros".

La masa es una enorme potencia, capaz "del mayor bien y del mayor mal". Cree que todo es posible y da exactamente igual. A veces, piensa sólo en sí misma, entonces prevalecen la actividad destructiva de los propios apetitos, y se olvida que "nobleza obliga": "Para mí, nobleza es sinónimo de vida esforzada, puesta siempre a superarse a sí misma, a trascender de lo que es hacia lo que se propone como deber y exigencia. De esta manera la vida noble queda contrapuesta a la vida vulgar e inerte que, estáticamente, se recluye en sí misma": R91.

Por desgracia, en estos momentos no se perciben síntomas de cambio auténtico en este triste proceso. La conyuntura es excelente y hay muchos buenos ejemplos de otros países, pero no se divisa aún un nuevo horizonte. Por todas partes se ofrece, en espectáculo, "el más chabacano aburguesamiento. Lo mismo en las clases elevadas que en las ínfimas, rigen indiscutida e indiscutibles normas de una atroz trivialidad, de un devastador filisteísmo": E166. Así, diríamos hoy, la tele-basura, que, en teoría, nadie ve, se ha convertido en la norma.

Todo esto ocurre tanto en la vida cotidiana como en los grandes acontecimientos. Hoy, apenas se escucha nada al hombre inteligente. Y es que nuestro buen burgués vive su estólida existencia con ignorancia invencible. No le 
importa la verdad, ni el "imperativo de selección" ni el "afinamiento de la raza". "El hombre-masa se siente perfecto": R74.

\subsubsection{La redención de las Provincias y la decencia nacional}

Para Ortega la política es "el arte de conseguir sin violencia lo que nos es rehusado" 22. Ahora bien, el hombre masa, como se siente perfecto, no piensa en mejorar su sustancia, cree que han de mejorar los demás. Y ese hombre se extiende, para nuestra desgracia, por buena parte de España. Así que la reforma de España es siempre una tarea ímproba, porque muchos españoles no piensan en "hacer historia" sino simplemente en aumentar sus negocios. Se necesita amor y pedagogía, y utilizar todos los recursos, pero de modo especial habrá que contar con la mujer para perfilar la nueva España con "un español más activo, más capaz y más despierto": P198.

Ahora bien, no hay que volver nunca a los tiempos pasados, en los que toda la nación parecía estarse sólo en Madrid e incluso, al menor descuido, todo el mundo había nacido en Madrid: el intelectual, el político, el artista era de aquí. Así, la mayoría de los españoles se sentían como de fuera, pues se confundía la nación con su centro. Por tanto, hay que mirar bien a todos los españoles, en su tierra, y cara a cara al país. Porque, en todas y cada una de las provincias, está el español real, con el que hay que hacer España, para nutrirlo de vitalidad, animarlo y elevarlo. Si se piensa de forma abstracta la nación, se pierde el sentido global y se cae en el aldeanismo. De ahí que la vieja política, creyendo que era profundamente nacional, no ha sido nunca, realmente, mas que madrileñismo y chulismo.

Por tanto, hay que centrarse, de verdad, en las personas concretas y sus derechos ciudadanos. Hoy la utopía es la gente, como lo ha repetido hasta la saciedad el pensador italiano G. Vattimo. Y cualquier otra "utopía, (...) es lo contrario de la política": P205. Pero, como en la vieja política dejaba de la mano de Dios a la gran mayoría de los ciudadanos, no resulta nada extraño la mala fama que ha cobrado, entre la gente, y la falta de credibilidad que tienen hoy los programas políticos, dado que todo se lo lleva el capital y la capital de la nación. Y, a las otras provincias se reparten unas migajas, caídas de la mesa del rico epulón capitalino y sus servidores, a saber: los palaciegos, gobernantes, parlamentarios, burocracia civil y militar, banca, pretendientes o/y ricos ociosos, prensa, instituciones científicas e intelectuales, juglares y actores.

22 J. ORTEGa y GASSET, La Redención de las Provincias. O. C. XI, 197, Madrid 1983.En adelante $P$. 
Pero España ni es esto ni se reduce al mundo de los burócratas, los intelectuales, los hombres del mundo financiero e industrial, que no son personal mayoritario. Además de Madrid, también están los hombres de las grandes ciudades, de las otras pequeñas capitales de provincia y la legión de distritos rurales que tienen avecinados. Entonces la clase media, y no los grandes del mundo, son el español real. Sin esa clase media de salvación, que diría Malègue, no se puede hacer una España auténtica, original y real, con visos de futuro.

Ahora bien, cuando en esto no se acierta, sino que se perpetra algo así como todo lo contrario, la gente huye de la política como alma que lleva el diablo, y se cierra en su pequeño mundo, o sea en su mundillo. Porque hoy, cree ganar más el que más grita a los "suyos", cuando lo que, realmente, pasa es que todo el mundo pierde. Pero cada uno se siente feliz pastoreando a los suyos y repartiendo influencias y prebendas que son el gran negocio de voluntades privadas y la vuelta, más encubierta, de la vieja política: "la oligarquía y el caciquismo": P219-20. Aunque, ahora, ya no se compran los votos individuales sino que se vende todo el distrito electoral junto, unido por sus intereses particulares concretos.

Así, el Parlamento pierde prestigio y es como el gran "Gulliver presa de los liliputienses", que dejan tocada la Justicia y la Hacienda. Entonces se crea algo así como un Estado, con unas mayorías que forman algo así como unos partidos, que desembocan en algo así como unos Gobiernos. Y, muy luego, "las organizaciones locales acrecieron sus pujos de independencia": P226. Esta fue, de hecho, la vida pública española en el primer cuarto de siglo.

Todo esto nos hace ver la necesidad de estar organizando constantemente "la alegría española" para llamar de nuevo, con perseverancia, a resurrección a nuestro pueblo. Para eso, se necesita magnanimidad, pensar en grande, a fin de abandonar el sonambulismo, pequeño burgués que ha paralizado siempre nuestra vida colectiva. Es decir: hay que dejar de "zorrear con los zorros", para no quedarse, al fin, cada uno con los suyos, y lanzar la nave española a la alta mar de la historia con un proyecto común a todos, de todos y para todos.

Así podremos incorporarnos a nuestro mundo con un español nuevo que a partir del español medio real, viva a nivel europeo tanto en su vida cotidiana concreta, en higiene, sanidad y educación, como en su vida pública, con todos sus ideales y esperanzas de modernidad y futuro responsable, libre y solidario, lejos del provincianismo chabacano que todo lo había arrasado e impuso "el triunfo de la chulería. El chulo es el rural madrileño": P230.

Hoy necesitamos volver al pueblo sencillo y auténtico para renovar "el sentido festival de la vida". Hay que conseguir que el provincianismo se 
pueda superar con un provincialismo sano que se incorpore y eleve para construir una verdadera nación, para desarrollar la riqueza insondable e innumerable de nuestros pueblos, y poner sensatez y paz al inveterado vicio de la chulería centralista. Con frecuencia, acostumbramos a echar la culpa de nuestros males y fracasos a fuerzas externas pero ha llegado el momento de asumir nuestra responsabilidad: nosotros seremos hoy y mañana lo que ahora, entre todos, queramos ser. En este proceso de regeneración democrática hemos de empeñarnos todos.

No basta con echar unos contra otros y saber muy bien lo que no se quiere; hay que saber, también, "lo que se quiere". De este modo, desde la vida concreta, de cada ciudadano y cada uno de nuestros pueblos, la vida del español medio habrá empezado a cambiar. Y así: "En cada rincón de España aumentará el pulso vital, en cada jornada acontecerán más cosas, habrá más obras, más proyectos, más amores, más odios. Y tal intensificación de la vida producirá automáticamente un afinamiento de las cabezas": P238.

Ahora bien, en este proceso global, juegan un papel decisivo nuestras instituciones. Aquí el papel del hombre político es buscar los instrumentos que puestos a funcionar provoquen, con rigor y constancia, "esa intensificación y dignificación del hombre medio español". Si esto se llega a lograr, todo lo demás "se nos dará por añadidura". Hay que sacar el español medio del fatalismo, que le cierra el horizonte vital, para que se convierta en un auténtico ciudadano con vida propia pero que se sabe también ciudadano del mundo. Hay que agarrar nuestro toro nacional muy bien por los dos cuernos para regenerar, con magnanimidad, la vida de nuestros pueblos y engrandecer, en profundidad, con permanente respeto a todos, el sentido nacional.

Así, hay que darle a este problema una solución elegante. Y en vez de lamentar siempre la dificultad que crea, se vaya a ella por directo, y se la enfrente con vigor para sacar de ella la solución. Este es el momento feliz, el tiempo oportuno y la hora fecunda de hacer una España mejor, rica en cada uno de sus pueblos y más rica en su ser global. Nada de nostalgia del pasado, pues, aunque haya sido bueno, no ha impedido el presente. Ese pasado y su historia será maestra de la vida que debe enseñarnos, muy, especialmente, lo que no debemos hacer.

Hay que llamar a nuestras gentes a vivir la ciudadanía, de ciudadanos libres en un país libre, no la de un Estado abstracto que para nada se acuerda de sus pueblos y sus gentes, ni en nada cuenta con ellos. Ahora bien, a los pueblos no se les puede mandar si no es obedeciéndoles, como decía F. Bacon para la Naturaleza: P244. Sólo si la vida local de los pueblos es intensa y rica, podrá ser exuberante y feliz nuestra vida nacional. Hay que organizar la vida local de modo que "llegue a su máxima potencia". Así, la política ha de ser 
siempre un sistema de soluciones al conjunto de problemas, que genere una interacción auténtica, entre todos, rica en solidaridad.

Se trata de provocar el diálogo entre todas y cada una de las partes del cuerpo que es el Estado. Y así como hay acuerdo en que la mejor unidad y sintonía del cuerpo legislativo, judicial y ejecutivo, no se consigue por la vía de su fusión, que crea la gran confusión antidemocrática, de la unidad de poderes, olvidando a Montesquieu, del mismo modo hemos de conseguir la unidad nacional a través del respeto y la promoción de nuestra diversidad de modo que cada uno de nuestros pueblos se sienta feliz en su propio ser y así contribuya, con todo su vigor, a la riqueza común del Estado nacional.

Por tanto, es preciso separar la vida local de la vida nacional para integrarla mejor. Sin esta nueva organización no hay unidad posible. "Esta es la obra de más sustancia que hoy puede hacerse en España". Es el supuesto riguroso, imprescindible, para todo lo demás. Sin esto no habrá nada y sin esta reforma el Estado español "seguirá siendo en lo esencial el mismo Estado ilusorio de los últimos cincuenta años": P247. Entonces será posible hacer verdadera historia, la historia de nuestro pueblo y la de cada uno de sus ciudadanos. Los ayuntamientos y las provincias son insuficientes. El municipio nos recuerda a los romanos, el concejo la Edad Media, la comuna los comuneros del s. XVI y a los comunistas del XIX. El Municipio es un buen centro administrativo pero no tiene entidad política, no puede organizar un pueblo en sentido nacional ni dar vitalidad política como no puede darla la familia por importante que sea.

Y una nación no se mantiene en pie como por arte de magia, como el sepulcro de Mahoma, sino la sostienen las fuerzas sociales de carácter político. Así un Estado se derrumba, sin grandes revoluciones, cuando le falta la asistencia de la vida ciudadana. Pero esa ciudadanía necesita de un ámbito político que pueda afrontar los problemas económicos como la exportación o la política de precios, p. e., de la producción olivarera de Andalucía. En esta caso el Municipio es antipolítico porque no puede afrontar los problemas reales del ciudadano. Maura comenzó a comprender esto y creó la mancomunidad. Pero se necesitaría crear una unidad política de ámbito bastante más amplio para que posea una auténtica "potencialidad de actuación". La Provincia tampoco es solución, tiene los vicios de la capital sin los beneficios del municipio. Así, una unidad política real y auténtica podría ser una comunidad amplia, como p. e., Andalucía, para que en un ámbito suficientemente grande "se produzcan ráfagas de dinamismo público que sacudan bien los nervios provinciales": P256.

Entonces, Ortega propone 10 grandes autonomías que podrían ser así: "Galicia, Asturias, Castilla la Vieja, País Vasco-Navarro, Aragón, Cataluña, 
Levante, Andalucía, Extremadura y Castilla la Nueva": P257. Nuestro autor piensa que esta nueva organización podría tener una gran potencialidad para la construcción histórica y real del Estado. Pone la vida local en manos de sus habitantes para que le apliquen sus mejores energías y la comunidad autónoma se gobierne a sí misma en todo lo que no sea estrictamente nacional. En manos del Estado quedaría el Ejército, la Justicia, parte de las comunicaciones, la vida internacional, el derecho a intervenir en los actos del régimen local, la opción constante de establecer servicios reguladores de orden pedagógico, científico y económico, en todo el territorio nacional.

Eso beneficiaría al ámbito regional y a la política estatal. Habría una Asamblea legislativa y fiscal en cada autonomía y un Gobierno emanado de aquella. Se crearían grandes capitales regionales, llamadas a dinamizar el ámbito Autonómico y desarrollar el nuevo ciudadano español, para una nueva vida política alejada una falsa utopía extravagante o fantasmagórica. Así, cada ámbito regional podría centrarse en sus problemas y participar a la vez en la creación de la nueva España. El nuevo futuro supone una nueva comarca cargada de electricidad política en el que resuena esta sencilla y ferviente palabra: “iEh, las provincias, de pie!”: P261.

Como es sabido, este proceso ya se ha desarrollado durante unos cuantos años en la política española, con un mapa un poco diferente al propuesto por Ortega, pero ahora se trataría de darle un nuevo impulso y de insistir en el diálogo entre las Autonomías y de estas con el Estado, sabiendo que ellas también son Estado.

\subsection{El papel de la Educación en la construcción Nacional}

Una gran nación sólo se construye por la educación, y esa educación no ha de llegar solamente a los estamentos cultos de la nación sino a todo el pueblo. De lo contrario cada uno seguirá su propio camino y tomará la educación "como un juego ingenioso del que no espera nada más". La nación debe ser educada en la más pura ética, más allá de los intereses particulares. Según Ortega, una nación o se construye por medio de la educación, o vive abocada a la revolución más perniciosa. Mc Clintock nos dice que Ortega "no se confió a la violencia sino a la razón"23.

Sólo así las personas actuarán según su nuevo ser. Porque: "un estado racional no se construye con disposiciones artificiosas, a partir de cualquier ma-

${ }^{23}$ R. Mc CLINTOCK, Man and his circumstances. Ortega as educator. Columbia University Press, New York 1971, 183: "Ortega commited himself to reason, not to force". 
terial existente, hay más bien que formar primero y educar a la nación para este estado. Sólo la nación que haya resuelto la tarea de formar al hombre perfecto mediante el ejercicio real, resolverá a continuación también la tarea del estado plenamente desarrollado": D134.

El verdadero progreso "consiste en la educación total humana de la nación". En esa educación ha de partir el pueblo de sus virtudes de "lealtad, sinceridad, honradez y sencillez". Así se construye un pueblo. Pero, a medida que la codicia y el ansia de poder de los jefes invade la libertad de la gente, el pueblo se hunde paulatinamente y termina por disolverse.

Los hombres verdaderos manan solidaridad, como nos han mostrado nuestros antepasados: "Con espíritu de piedad, honradez, modestia y civismo. Para sí mismos necesitaban poco, para empresas comunes efectuaban ingentes gastos. Raras veces sobresale y se distingue un nombre, todos mostraban el mismo sentido y entrega a la comunidad": D136-7.

Un pueblo necesita, además, un relato auténtico de su propia historia, de su intrahistoria verdadera, no de una especie de cuento que cada cual cuenta como quiere. Ese relato que, como la verdadera filosofía, ha llegado a "la misma esencia de la única vida, de la vida pura y divina, nace simplemente como vida que permanece, siendo vida en toda la eternidad y además siendo vida única y no como vida de ésta o aquella vida": D143.

Un pueblo es: "El conjunto total de hombres que conviven en sociedad y que se reproducen natural y espiritualmente de manera continuada, que está sometido en su totalidad a una determinada ley especial del desarrollo de lo divino a partir de él": D160. Esta ley determina y consuma el carácter nacional del pueblo a partir de ese elemento quasi divino. Pues, como dijeron, en su día, Salinas y Lorca: cada cosa tiene su misterio y el poeta nos lleva al misterio de las cosas. O como lo decía Antonio Machado: "el alma del poeta se orienta hacia el misterio".

Sin esta vida íntima, divina, ni hay pueblo, ni nación, ni carácter nacional, ni vínculo interno vital, ni idea de sociedad, ni de humanidad. La patria, la vida de todos, es una experiencia eterna sin la cual no es capaz el hombre ni de amarse, ni de respetarse, ni de solidaridad. Además: "El Estado quiere una cierta justicia y una paz interna, quiere que cada individuo encuentre con su trabajo el alimento y la prolongación de su existencia física mientras Dios quiera conservársela".

Se puede preguntar si la libertad y la vida han de ser inmoladas a cuestiones supremas. Fichte afirmará: "Aquí no vamos a decidir si a una nación puede decírsele esto con verdad; lo que sí está claro es que un pueblo originario necesita libertad, que la libertad es garantía de su persistencia origina- 
ria, y que en su subsistencia soporta sin peligro alguno un grado cada vez más elevado de ella": D163.

En cualquier caso, sólo el amor a la patria puede gobernar el Estado para poder proponerle una meta superior, por encima de la paz interna, la propiedad, la libertad, la vida y el bienestar. Sólo con este “objetivo superior”, el Estado reúne una fuerza armada. Y sólo por un objetivo así se abandona la situación previa, de leyes y vacilaciones, para hacer un nuevo mundo. Como lo decía Azaña: nadie da la vida por un pantano...

Por eso, y "a pesar de todo, sigue siendo verdad para siempre que, con su entrega, para la vida toda de la posteridad, ha llegado más cielo a este lado de la tumba, desde la tierra se han levantado miradas más alegres y valientes, los espíritus se sienten estimulados con más libertad y, tanto los descendientes de sus enemigos como nosotros, sus descendientes, saboreamos hasta hoy los frutos de sus esfuerzos": D165.

Así, los pueblos germánicos se enfrentaron a los romanos. Ellos no eran ciegos a los valores de aquellos pero, así, no podían ser libres e independientes, ni ser ellos mismos, por eso también les comprende un escritor romano cuando dice: “LLes queda alguna otra cosa que no sea mantener la libertad o morir, antes de convertirse en esclavos?": D166.

Pero, verdaderamente, no son los brazos ni la fuerza de las armas la que trae la victoria sino "la fuerza de ánimo", el ansia de autenticidad y de ambición eterna. De ahí se deduce que el Estado no es primario y fundamental, "sino que es simplemente el medio para el objetivo superior de la educación", y el "amor a esta formación eterna" ha de vigilarlo el Estado con la independencia del pueblo. De ahí que la libertad y la ciencia se ejerce en todo el Estado.

Por lo demás, la educación es para todos los ciudadanos. Y, así, superadas las mezquindades locales, en Alemania, "considerada como un todo, se dio el más alto grado de libertad de investigación y de comunicación que jamás haya poseído un pueblo": D169. Sólo la educación auténtica ofrece esa emoción noble del amor auténtico y poderoso a la patria.

El amor patrio debe guiar a todos los Estados por medio de la justicia, y ese sentido de lo justo, es necesario que anide en todos los ciudadanos. Sólo la educación puede salvar la independencia del pueblo en su propia identidad, y hacerle mayor de edad en todas las situaciones y tiempos, aún los más difíciles, cuando "ya no nos queda más que la palabra, e incluso ésta está siendo dificultada y reprimida por todos los medios". Pero, la educación verdadera, la que hoy puede salvarnos, es una "recreación total del género humano". 


\subsubsection{La auténtica Educación}

Hasta ahora, la educación insistía en la naturaleza, en la materia, en la carne, es hora de retornar al espíritu como el único fundamento posible de un Estado auténtico. Sólo así se puede trasmitir el amor a la patria eterna, del que ha de surgir su auténtica defensa así como el ciudadano pacífico y verdadero. Al perfeccionar todo el hombre, se le habilita para la vida y se le cura de los males que le oprimen. Es así como la educación se introduce en la vida, tal como lo propuso y practicó J. H. Pestalozzi, al que, más allá de sus dificultades y fracasos, ha sostenido un impulso todopoderoso e invencible: "el amor al pueblo pobre y desamparado".

Este amor lo hizo vida de su vida y le llevó a conseguir mucho más de lo que nunca podía haber soñado: "Lo único que quería era ayudar al pueblo; pero su creación, tomada en toda su amplitud, eleva al pueblo, elimina todas las posibles diferencias entre éste y la clase culta, proporciona una educación nacional en vez de la pretendida educación popular y sería capaz de rescatar a los pueblos y a todo el género humano de la profunda miseria actual"24.

En primer lugar, hoy se requiere una pedagogía firme y segura, escrupulosa, nada de andar a tientas. Se trata de estimular la actividad espiritual del educando, su pensamiento y su vida, en la que descubrirá el mundo del amor. La educación anterior dejaba al educando en las tinieblas y las sombras, sin permitirle llegar a la verdad ni a la realidad auténtica.

${ }^{24}$ DA 180. Ortega recibe la influencia de Pestalozzi principalmente a través de Paul Natorp, que fue con Cohen su mentor en Marburgo y, uno de los autores más influyentes en su teoría social y política. La sombre de Natorp siempre, es un apartado de la Tesis doctoral de D. Natal. En España, se tradujo de P. NATORP, Pestalozzi: su vida y sus ideas. Barcelona 1931. "Natorp y otros pensadores posteriores han demostrado que Pestalozzi no fue un mero practicón empírico y mecanizado de las primeras letras. Fue un espíritu filosófico, que sin reducir su pensamiento a un sistema cerrado y esquemático, arrojó en todos los campos de la cultura general multitud de ideas y de propósitos, que poco a poco han ido renovando aquí y allá los sistemas y procedimientos de enseñanza general": M. ALLUÉ SALVADOR, La obra viva de la educación social, La Nación, en I. NAVARRO CANALES, El Centenario de Pestalozzi en España. Avila 1927, 60. En adelante CP. La Región de Santander decía: "Su única preocupación fue la formación de ciudadanos, pero ciudadanos cultos, honrados, laborioso, hombres en fin": CP210. R. LLOPIS, en El Socialista, aseguraba: "jTestamentarios de Pestalozzi...! Todos nos consideramos un poco sus testamentarios. Lo son, en realidad, todos aquellos que se preocupen de emancipar a los hombres por la educación":CP34. El Diario Universal pedía: "Escuela y Despensa, el programa único de Costa, sigue teniendo aún en España palpitante y recia actualidad, precisamente por esa desatención global y aún particular, que nos ha merecido siempre la magna cuestión de la educación racional, científica, lógica, inteligente y cordial; la educación en fin, que Pestalozzi impulsara",...: CP44. Fichte, Goethe, Herder, Herbart y Klopstock, entre otros, le alabaron y respetaron: CP 41, 210. 
Así, se propuso rescatar a los niños pobres del abandono con la escuela, y se les introdujo en la lectura y la escritura como tema fundamental de la educación primaria, del leer y el escribir hizo los mejores auxiliares de la enseñanza. Fichte desea una educación nacional. No la que da al niño una educación elemental, para sacarle corriendo de la escuela, porque, "entonces es mejor ahorrar también esta mitad y aclarar ya desde el principio que no se pretende ayudar a la Humanidad": D182. Y, en cuanto a los eruditos, es fundamental enseñarles, también, a pensar.

Sobre la "educación familiar", Fichte considera, sin quitar valor a Pestalozzi, imprescindible que los niños salgan de la casa familiar para dedicarse plenamente al estudio. Esto sería así en principio. "Solamente después de que toda una generación haya pasado por la nueva educación se podrá deliberar qué parte de la educación nacional se quiere confiar al hogar" D183.

Por otro lado, antes de introducir al niño, en los temas del lenguaje, hay que enseñar un $\mathrm{ABC}$ de la sensaciones para que tenga una visión espiritual de la vida que nunca le abandonará. Luego vienen las matemáticas, los números y el mundo físico. Pero, es fundamental "ser iniciado en el diseño de un orden social del hombre y en el amor a este orden como paso segundo y fundamental de su formación": D185.

También es importante iniciar a un ABC de la habilidad corporal, con ejercicios sencillos de empujar, arrastrar, llevar, lanzar, luchar, girar... Es la educación del cuerpo. Esta formación adecuada en la habilidad corporal, "es solamente medio y ejercicio previo a su segunda parte esencial que es la educación cívica y religiosa": D189. Con esta educación cívica y religiosa se concluye su formación y el educando puede abandonar la escuela. Ese método tiende a crear un "ser firme, definido y constante".

Se trata de formar un hombre de buena voluntad firme y decidida, con una norma segura y eficaz. Pero dado que "el hombre sólo puede apetecer aquello que ama, el amor es el impulso único y al mismo tiempo infalible de su querer y de toda sus emociones e impulsos vitales": D67. La auto-educación suponía que todo mundo ama su bienestar y el interés de la comunidad, por encima de su egoísmo, pero no ha resultado cierto. En cambio, aprender a amar lo bueno, en sí mismo, lleva a una complacencia íntima, que establece, de por sí, "las bases de una voluntad inquebrantable y buena". El educando debe aprender a crear imágenes que sean como arquetipos de su creatividad y de su deseo de aprender a hacerse hombre en plenitud.

No basta formar buenos trabajadores, sino que el mismo educando "esboce libremente la imagen de un orden moral de la vida, que de hecho existe, capte esta imagen con el amor a su vez desarrollado ya en él y que este amor le impulse a manifestarla de hecho en la propia vida". 
Cuando esos ideales los hayan encarnado en grupo, podremos pensar que los educandos están preparados para salir al mundo social animados por el amor y la práctica de esos ideales como un verdadero arte, ante las exigencias que el mundo les presentará.

\subsubsection{Educación y Religión}

Además del nivel humano, la vida personal y la vida espiritual es un eslabón de la cadena de la vida, que ha de considerarse sagrada. La religión, "basada en el vivir de nuestra vida en Dios, debe dominar también en la nueva época y en ella debe ser cuidadosamente configurada": D82. Pero la religión que utilizó a Dios para favorecer el egoísmo debe ser enterrada con la época pasada. "La educación en la verdadera religión es por tanto la última tarea de la educación". Ella debe afianzar plenamente su libertad y su integridad ética. Así lo entendió siempre, en España, la Institución Libre de Enseñanza, nacida del krausismo, nacionalizado español, por el célebre soriano don Julián Sanz del Río.

La religión debe dar sentido a la vida, aunque la ética bastara para organizar humanamente la convivencia. En efecto: "el hombre tiene su sede no sólo en el mundo sensible, sino que la verdadera raíz de su existencia, según vimos, está en Dios". La religión debe actuar, sobre todo, como impulso, y sus teorías nunca han de ser ideas muertas, especialmente cuando más se necesitan para formar al hombre íntegro. Pues la religión es el amor a la vida íntima de Dios en nosotros, y sobrepasa la educación "pensada para todos y para toda la nación".

La religión tiende a formar al hombre auténtico y vital, desde las raíces de su vida y no sólo en apariencia, con entendimiento claro y voluntad pura. Entonces, el amor verdadero, lo unifica e integra todo. "Más aún, el amor es ahora contento consigo mismo, alegría de sí mismo, gozo de sí mismo, y por tanto bienaventuranza. $Y$ así queda claro que vida, amor y bienaventuranza son absolutamente uno y lo mismo" 25 . Es la religión de la vida predicada por Ortega, nacida del respeto total a la vida y al Absoluto proclamado en el Ideal de la Humanidad para la Vida difundido en España por Sanz del Río, Salmerón, Fernando de Castro y otros.

Eso hace que el individuo busque una educación verdadera, más allá del egoísmo, que no se encierra en un yo aislado que quiere vivir feliz de forma egocéntrica. La verdadera educación supera el ser humano frío e indiferente

25 J.G. FICHTE, La exhortación a la vida bienaventurada o la Doctrina de la Religión. M. 1995, 22. En adelante DR. 
ante los otros. Entonces, el hombre se entiende a sí mismo desde un sentimiento de amor como "un 'tener que ser' para toda la eternidad". Este hombre nuevo crea un nuevo orden de cosas y un mundo nuevo.

Si la Humanidad no quiere verse reducida a pura nada, tiene que "hacerse a sí misma para eso que aún tiene que llegar a ser". De hecho tanto el amor humano como el divino es "la pasión por el ser": DR130. Y es, de por sí, "el auto-llevarse y auto-poseerse del mismo Absoluto". "El amor es, por tanto, superior a toda razón, y es la misma fuente de la razón y la raíz de la realidad, y el único creador de la vida y del tiempo": DR177. Así, el pensamiento auténtico y la filosofía verdadera es "la ciencia general del amor" como asegura Ortega en las Meditaciones del $Q$.

$\mathrm{El}$ verdadero destino del hombre es "convertirse con libertad en aquello que es genuinamente". Este hacerse a sí mismo llega hoy al centro de la historia como dimensión fundamental de su desarrollo libre, con un nuevo afán de claridad desde el misterio del ser. Pues no es la religión una creencia de oídas sino un proceso viviente y activo en el que: "El mismo puro pensar es la existencia divina y, al revés, la existencia divina en su inmediatez no es más que el puro pensar". Contemplar esa existencia divina sin velos, es ya la vida verdadera y bienaventurada.

La profecía de una nueva vida basada en la "complacencia en lo bueno", es hoy de nuevo posible e incluso muy necesaria. Y no está reservada a las clases altas ni prescinde del elemento metafísico. Nuestra época no debe desesperar de sí misma, pues un día la nueva educación será aceptada con alegría. Hay que llamar a toda sociedad a nueva resurrección, un verdadero milagro, que entre todos podemos y debemos hacer o provocar como ocurrió en otros tiempos.

Así, concluida, por fin, "la formación cívica y religiosa se concluye la educación, el educando puede abandonar la escuela”: D190.

\subsubsection{Educación y Sociedad}

El niño tiene una tendencia natural a la claridad, al orden y un buen deseo de aprender. Con este amor a la ciencia, el desarrollo de la educación es más fácil y seguro. Hay, también, en el hombre un amor que le une a todos en "una comunidad razonable, unitaria y de iguales convicciones": D191. Y, no se trata de formar sólo eruditos, es un deber imprescindible de la educación "desarrollar ese segundo amor", como defendía Pestalozzi con gran apasionamiento. 
Para Fichte, el hombre no es un egoísta sin más sino que hay en el niño una tendencia al respeto, a lo justo, a lo bueno, al autodominio, a la ética y a la veracidad. El niño busca la aprobación del padre y de su amor, solicita que advierta su afán de ser bueno. La indiferencia y la falta de comprensión, permanente e injustas, ahogan en el niño ese amor. El niño respeta y necesita del respeto. El adulto tiene en sí mismo la medida de la propia estimación y busca ser estimado por los más dignos de estima. Algunos permanecen siempre niños y necesitan de constante aprobación. Pero, todos necesitamos ser valorados y estimados, como nos recuerda A. Maslow.

Al niño hay que orientarle a lo ético. Ahora bien, la raíz de toda ética, está en la superación de sí mismo, en el dominio de sí, no en el ser agradable ni en reconocer los méritos, ni en alentar la vanidad. El reconocimiento auténtico es la buena conciencia propia, el acuerdo real consigo mismo, el valor de la propia estima y la auténtica confianza. Donde hay varios educadores es bueno que el niño elija uno de su confianza, como consejero y confidente, que sea como un amigo, que le anime en sus consejos. Por medio de estos tutores debería conseguir un afán de superación y dominio de sí mismo que aliente la confianza y autonomía adecuadas a su edad.

Cuando resulta que: "Un hombre sabe por sí solo lo que hay en él y no necesita ya de un testimonio extraño, sino que es capaz de juzgarse a sí mismo con rectitud, a partir de ese momento es mayor de edad": D195. La complacencia en lo justo y lo bueno debe alejar todo temor y ser el único móvil de toda vida futura. Ahora bien, esa complacencia no consiste en sentirse simplemente satisfecho como se siente un cachorro. Porque, con el mal ejemplo, el hombre se hace peor, más egoísta e insensible a los demás.

De hecho, los más jóvenes imitan el mal ejemplo de los adultos y, así, se hacen peores al ser igual que nosotros. Es, pues, necesario aislarlos de este contagio, de modo que vivan "sólo con sus maestros y superiores", separados totalmente de los adultos. Además, se ha de tener siempre en cuenta que la educación debe ser para ambos sexos porque de los dos se forma la sociedad. "En el centro educativo tiene que exponerse sin reservas y formar en los educandos la relación de ambos sexos entre sí: protección valerosa de una parte y asistencia cariñosa de otra": D198. Así lo hizo en España la Institución Libre de Enseñanza al promover la armonía entre el hombre y la mujer, el respeto a la mujer, el amor al cuerpo y a la Naturaleza.

Una condición esencial, de la nueva educación, es enseñar que aprender y trabajar van juntos. Los centros de aprendizaje deben mantenerse por sí mismos y todos deben colaborar y centrarse en lo principal. Cada persona debe aprender a valerse por sí misma a ser independiente, aunque económicamente no fuera necesario. De lo contrario, se acostumbrará muy pronto a 
arrastrarse ante los otros, a adular a los poderosos y a dejarse utilizar, incluso por los iguales.

Hay que enseñar a vivir con honor. Las personas infames tienen en común que no han aprendido a trabajar y temen el trabajo. Hay que educar en la laboriosidad con oficios adecuados, aprender a producir para las propias necesidades, y para el bien del Estado y la familia. Y, deben estudiar todos los que tengan cualidades, sin mirar su condición social, por el bien de la nación. El espíritu creador debe disponer de la mejores condiciones, en su formación, para forjar el futuro.

\subsubsection{Educación y Pueblo Nuevo}

La educación debe transformar al hombre. En Europa la educación ha partido de la Iglesia. Al principio, era sólo un problema de los padres y sus intereses. Por lo general, el cristianismo educaba para la salvación de las almas con un poco de lectura y escritura. No hubo una educación del pueblo, pues la educación general estuvo siempre desatendida. Y si se planteaba ese problema, la respuesta era la misma: "El Estado no tiene dinero para esos fines" (D206), pero siempre lo ha tenido para los Ejércitos.

Una buena educación hará innecesaria gran parte de ese gasto, pues el amor a la nación, recibido en la educación, facilitará todo lo demás. La educación también favorecerá la economía, pues preparará una clase trabajadora con menos reformatorios, centros penitenciarios y caritativos, y otras instituciones de "producir pobres".

A veces, se ha pensado en todo menos en la educación, y se ha enseñado a la gente a vivir de una manera cobarde e indigna. Por eso, aunque la resolución del problema sea a largo plazo, es necesario comenzar de nuevo y buscar algo mejor. Hay que apoyarse unos a otros, e insistir en innovar siempre. Pues solamente la educación puede alejarnos del salvajismo y la barbarie. Es muy curioso que para hacer la guerra se obliga a todos a los máximos sacrificios, pero para educar y para llevar a los hombres a la libertad siempre se ponen reparos.

Todos los grupos humanos deben impulsar esa tarea. Cada uno debe estimular a los demás, eliminar irresoluciones y luchar por lo mejor. Lo importante es empezar, el ejemplo arrastrará. Siempre ha habido próceres de la educación. Ahora, se trata de extenderla a todos, con todas las garantías de los mejores valores ciudadanos. Sólo así se podrá eliminar la servidumbre. En el niño se "halla toda la plenitud inocente y abierta de la Humanidad", pero ne- 
cesita ser iniciado en el arte de la vida. Y, como todo educando se convertirá, a su vez, en educador, poco a poco esa educación irá allegándose a todos.

Pero, además, a los que la pobreza impide el estudio, hay que darles también de comer. Este será un ejemplo señero para la posteridad: educar a aquellos a los que la vida o la familia negó esa posibilidad. Así podrán ser los futuros sabios, legisladores y salvadores de la Humanidad.

Para comenzar, "se necesitan ante todo maestros y educadores competentes. La escuela de Pestalozzi ha formado ya tales hombres y está siempre dispuesta a formar más": D216. Al principio habrá que crear como un seminario de educadores, y formar también en él algunos jóvenes que aprendan a enseñar practicando lo aprendido. Con buena voluntad, se pondrá en marcha el nuevo plan. Hoy, este proceso se ha generalizado en las Facultades de Pedagogía.

Es necesario cultivar siempre el amor a lo justo y lo bueno, de lo contrario, nos dejaremos llevar por cualquier orden de cosas sin preocuparnos ni siquiera por nosotros mismos. Llegaremos a acostumbrarnos a la sumisión y a la esclavitud, olvidando nuestra dignidad y libertad, y, así, perderemos, incluso, la propia identidad. No podemos vivir como troncos, sin sentido ni carácter, ni tomar la vida a broma. Hay que formarse un criterio de vida comunitaria, para reformar y transformar la vida pública al implantar la "nueva educación nacional".

\subsubsection{La verdadera grandeza de un Pueblo}

Cada pueblo debe gobernarse a sí mismo, velar por su autonomía y tratar sus propios problemas sin sentirse condenado a "imitar viejas formas pasadas". Si el pueblo se olvidase de sí mismo, el pensador tiene la obligación de recordarle su deber y sacarle de los sueños. La falta de claridad es el peor de los males y conduce a las tinieblas de la complacencia en el servilismo pusilánime, en el enanismo nacional, a la humillación e indignidad de las personas y a ser complaciente con la corrupción general.

Hay que crear una nueva ética, una nobleza de espíritu que sea capaz de pensar en grande, superar la mezquindad y la abulia reinante con una auténtica crítica de la razón indolente (De Sousa). Hay que salvar a la especie humana de la ruina, comenzando por nuestra propia casa. Frente a la sumisión, el servilismo y la esclavitud el hombre, debe buscar auténtica "autonomía, verdadera libertad, enaltecimiento y ennoblecimiento".

Hay que luchar por la dignidad de los pueblos, sin complacencia en la violencia, que acaba con la paz de las naciones por medio de la rapiña y el sa- 
queo, y reduce todo a "hacer dinero de la forma más rápida posible para continuar su camino de nuevo y volver a hacer dinero". Con pueblos así, se puede devastar la tierra y convertirla en un caos sombrío, pero nunca crear un mundo solidario universal. "La lucha con las armas ha terminado; surge, si así lo queremos, la nueva lucha de los principios, de las costumbres y del carácter": D243.

Hay que cultivar las virtudes cívicas: el amor al deber, la rectitud insobornable, la lealtad ciega a los amigos y a la patria, frente a la rivalidad de los individuos y de los pueblos. Hay que respetar a los otros. Los pueblos con verdadera clase no crean el vacío entorno para afianzar su identidad ni tratan de asimilar, a todos, a su estilo e idiosincrasia.

Sólo los conquistadores y colonizadores piensan que toda resistencia es pura rebelión criminal, sublevación contra la ley divina, y que su conquista está llena de bendiciones para el pueblo sometido. Esta forma de pensar es un "sarcasmo insolente", adulador del poder y burlador de los vencidos. Para llegar a este talante, no hace falta la maldad ni la traición más siniestra, basta con la irreflexión y la desidia pimpante que conduce, en directo, a la banalidad del mal (H. Arendt).

Todo hombre es imperfecto y siempre comete errores, pero si queremos evitar llegar a esos extremos, además de la buena voluntad es necesario un "entendimiento justo y salvador". Para comenzar a cambiar hay que renunciar a la irrisoria y repugnante costumbre de "ofrecer a nuestros gobernantes en toda ocasión burdo incienso, no respetando la razón ni el decoro, las buenas costumbres ni el gusto". Todo hombre mezquino es vanidoso y amigo de aduladores, pero la verdadera grandeza aborrece las estatuas y homenajes prematuros, pues el tiempo es el mejor juez. Y, porque, además, verdaderamente: "Grande es sólo aquello que es capaz de ideas que traen consigo la salvación de los pueblos y que se entusiasma por ellas; pero en cuanto al hombre actual, dejemos que sea la posteridad quien lo juzgue": D251.

\subsubsection{La grandeza Nacional y el Estado Internacional}

Para U. Beck, al comienzo del tercer milenio, hay que sustituir la política realista nacional, que persigue nacionalmente los intereses nacionales, por una política realista cosmopolita. Pues cuanto más cosmopolita sea una política, más nacional y eficaz será. En la era de la globalización, la creación de una tupida red de dependencias transnacionales, conduce a la recuperación de la independencia nacional. Eso ocurre, precisamente, ante el poder que ha adquirido la economía mundial. 
Parece que la globalización económica ha tomado la delantera al poder político, pero esto no tiene que ser un destino inevitable. Para eso es necesario que la política cosmopolita perfore la "barrera del sonido nacional", ya que: "Los Estados transnacionales son los mejores Estados nacionales"26. U. Beck cree que así como la paz de Westfalia, al separar el Estado de la Religión, puso fin a las guerras civiles confesionales, del mismo modo, al separar el Estado de la nación, se pondrá fin a las guerras mundiales (civiles) nacionales. El nuevo Estado de las patrias dobles superará la antigua unicidad de la patria homogénea, creando una nueva soberanía. Este Estado cosmopolita ya se practica cuando se ponen "la democracia y los derechos humanos por encima de la autocracia y el nacionalismo".

La ganancia federal de la soberanía, en la Constitución fundacional de los Estados Unidos, es un ejemplo a seguir. Donde antes sólo había la alternativa entre autodeterminación o sumisión nacional surge ahora la nueva opción del federalismo estatal cosmopolita. Esta especie de "tercera vía" parecerá al principio, a los antiguos nacionalismos duros, puramente intelectual. Pero si se intentan dar pasos se comprobará su realismo, porque contribuirá a la pacificación de los nacionalismos crónicos y a la integración internacional. Si la mirada nacional queda atrapada en su círculo auto-confirmador culturalmente pesimista, querrá imponer su axiomática nacional que conduce, como ya se ha probado demasiadas veces, a un callejón sin salida.

Así, pues, es necesario avanzar, hacia una transnacionalidad y una transoberanía cooperativa. Se trata de otra mirada y de otra política que no puede sustituirse ni por la economía ni por la cultura, pues, sin política no hay solución a los problemas económicos ya que el consenso ciudadano no se compra ni se supone. De ahí, que algunos, ante la falta de cambio y renovación política, sientan la tentación de volver al viejo régimen. Por otra parte, la transnacionalización del Estado ha de pagarse, hasta el último céntimo, en pequeñas y grandes monedas de la autonomía nacional, de modo que el Estado cosmopolita puede y debe hacerse aún más cercano al ciudadano y a sus preocupaciones candentes: U240.

Los movimientos ciudadanos y las organizaciones no gubernamentales van a ayudar al nuevo Estado, en esta tarea, pues se convierten en abogados del bien común que recuerdan al político los derechos ciudadanos concretos. Sólo esta Gran Política podrá ganarse el asentimiento libre y responsable ciudadano, y sacar así del desprestigio a la política al que le ha empujado el neoliberalismo que parece que defiende los derechos de unos pocos. $\mathrm{Y}$, al en-

26 U. BECK, Poder y contrapoder en la era global. Paidós, Barcelona 2004, 141. En adelante $\mathrm{U}$. 
tender la liberalización como una privatización para algunos, se ha granjeado ya "un coro de agrias carcajadas" en Gran Bretaña, en el tema del ferrocarriles. Además, conduce a una seguridad social más cara, deficiente y despilfarradora, o que simplemente no existe como en EE. UU.: U249-250. Esa privatización en casi nada disminuye la corrupción ni el derroche público ni la mala gestión como cree la leyenda. Son las contradicciones de la privatización.

Estas contradicciones, también aparecen en el mercado de trabajo y en la movilidad del capital: Nadie encierra a los inversores en las salas de los aeropuertos para preguntarles sobre sus intenciones inversoras, aunque sean muy malévolas, pero sí se encierra a los trabajadores inmigrantes. Hay aquí una asimetría llamativa entre capital y trabajo. Nadie habla de "asilados capitalistas" aunque puedan hundir, con sus maniobras, la economía de una nación o no se integren apenas en la cultura nacional y local. Hoy, se presenta como un progreso liberal la globalización del capital, y como un acto criminal la globalización del trabajo.

Por tanto, se necesita un nuevo pacto político que equilibre el poder entre política y economía y conduzca al capital internacional a aceptar unas nuevas reglas de juego cultural y político en los Estados transnacionales revitalizados cooperativamente. Sólo así es posible dar significado real al Estado transnacional con una ampliación de la soberanía política nacional, que dará un nuevo equilibrio al antiguo Estado y al nuevo orden internacional que pueda sanar los viejos conflictos nacionalistas y la dependencias imperialistas crónicas. Así, se hará posible una re-politización positiva de la política que defienda los derechos del ciudadano.

E. Morin ha hecho una crítica durísima de los Estado nacionales como "monstruos paranoides", porque: "Se tratan entre ellos con un enloquecido furor sangriento. No reconocen ley más elevada que su voluntad bárbara. Los pactos siempre son papel mojado que cualquiera nueva correlación de fuerzas rompe. Son incapaces de amar y carecen de conciencia (Gewissen)": U304. $\mathrm{Y}$, en fin, U. Beck piensa que: quien sólo piensa nacionalmente pierde, la soberanía debe ampliarse con un nuevo pacto social universal. Hay que ennoblecer los problemas mundiales, la mirada cosmopolita nos conduce a soluciones reales de los problemas, y actuar de esa forma significa actuar en un mundo con fronteras permeables.

Por otra parte, la defensa de los derechos humanos es una fuente de poder cosmopolita y une a todos los ciudadanos. De ahí que sólo un Estado cosmopolita puede garantizar los derechos, incluido el de autodeterminación, cuando responde positivamente a la pregunta crucial de todas las lealtades: 
“¿qué clase de otredad construyen y cuál marginan, y cómo se comportan respecto a estos culturalmente otros que crean?".

Para U. Beck: "No es que los actores económicos mundiales sean más poderosos que los Estados, es que se han desprendido antes de las miopías de la ortodoxia nacional: esto es lo nuevo". Y, el que espere el retorno de la política desde el Estado nacional unirá su voz al coro de lamentaciones por el "final de la política". Hay que buscar un nuevo Estado para la Segunda Modernidad que va del Estado nacional al transnacional. Pero, para eso, hay que ayudar todos: gobiernos, partidos, movimientos sociales y el mundo de la economía, ya que después del desencanto del Estado neoliberal no hay salida tampoco para ésta sin una nueva política.

Así, no es posible seguir, el que insista en el Estado nacional será atropellado y desquiciado por la realidad misma. Es necesario buscar un nuevo poder inclusivo, no excluyente como ha sido el Estado étnico que hace de los vecinos enemigos y no sólo es hostil a los extranjeros, sino con sus propios ciudadanos, pues excluye también a sus conciudadanos en una guerra de todos contra todos. Pero, la mirada cosmopolita no sustituye la nacional. Ambas coexisten entre lo establecido y lo alternativo para: "impulsar la internacionalización del Estado nacional mediante su integración en los contextos económicos mundiales y organizaciones supranacionales".

Además, los derechos humanos conciernen a todos y el principio de subsidiaridad concreta la resolución de los problemas de los ciudadanos. Así, se defienden unos y otros. Decía B. Franklin: quienes "renuncian a libertades esenciales para conseguir pequeñas seguridades provisionales no se merecen ni la libertad ni la seguridad". Hoy, después de la Patriot Act, su teoría no queda nada de moda, pero habrá que luchar por ser ciudadanos libres, porque así como el dogma de la modernidad nacional decía que: "el terruño no miente", "El dogma de la modernidad cosmopolita es: 'Los derechos humanos no mienten"': U387. En efecto, estos derechos son una utopía irresistible puesto que minan la legitimidad nacional de los Estados que se resisten a su implantación y asentamiento. Por tanto, el régimen cosmopolita debe favorecer la unión fecunda entre democracia y derechos humanos y fortalecerla mediante instituciones internacionales capaces de actuar y mediar en los conflictos.

U. Beck nos ofrece una teoría de total actualidad que dará mucho que hablar. Incita al diálogo y a la discusión de un tema decisivo para nuestro mundo, y propone una gran tarea de libertad y responsabilidad a los ciudadanos y a las organizaciones sociales. 


\section{Conclusión}

La chispa de la grandeza del pueblo debe prender en todos los corazones, de modo que aliente una conciencia segura y alegre que nos lleve realmente a construir una patria en este mundo para no "conformarse únicamente con la celestial". Cada uno debe tomar posición por sí mismo sin esperar a que lo hagan los demás. No hay que exigir a los demás sino exigirnos a nosotros mismos, si es que hay en nuestra vida savia y sangre y no estamos de cuerpo presente.

Por lo demás, aquellos que nos critican nos llaman también a resurrección. El futuro depende de nosotros sólo. Es necesario superar este tiempo, que ha sido demasiado poco honroso en nuestra nación, para no vivir humillados, arrinconados, y con la bandera del pueblo desteñida poco a poco. Hay que crear una vida aceptable y honrada, "regeneradora y restauradora", principio de una nueva época digna de nuestro linaje.

Es preciso no abandonarse a los albures de los tiempos. Nadie nos puede suplir en esta hermosa tarea, y "nada en absoluto os podrá ayudar más que vosotros mismos". Porque, en definitiva: "el que alguna vez nos vuelva a ir bien, depende exclusivamente de nosotros, y seguramente nunca volveremos a disfrutar de bienestar si no nos lo procuramos nosotros mismos": D260.

Esta es una tarea de todos y especialmente de los jóvenes, más sensibles a todo lo bueno y útil, más cercanos a la inocencia de la naturaleza y más extraños a la corrupción, al egoísmo, la desidia y la holgazanería, y con más ganas de ser mejores y de cambiar el mundo. Es necesario pensar con claridad y no dejarse enredar por la rutina. La edad avanzada fácilmente se deja conquistar por la ineficacia y el egoísmo, y se convierte en la fuerza que impide todas las mejoras del bienestar común. Pero la edad no es lo decisivo, todos podemos crecer en libertad y lucidez mientras nos dure la vida.

Los mayores también pueden ayudar con su experiencia, o, por lo menos, no estorbar, concientes de que si hubieran cambiado el mundo, nos habrían salvado antes y habríamos superado el problema. Los hombres de negocios, criticados como charlatanes superficiales y engreídos, fanfarrones, despectivos con la ciencia y el pensamiento y ajenos la escuela, deben demostrar, con su apoyo a esta causa tan noble, que sus acusadores no tenían razón.

A los escritores, sabios y pensadores, se les convoca también a esta tarea para mostrar que no han huido a un país extraño y no han dejado a un lado, despreciado ni desdeñado, el mundo real. Pensadores y hombres de negocios se necesitan mutuamente como la cabeza y el brazo. Los hombres de letras, con frecuencia, tienen responsabilidad especial porque: "La causa evidente de la apatía de la época es que ésta se ha insensibilizado con la lectura de vues- 
tros escritos". Hay que comenzar la tarea de nuevo, enseñar a los hombres de negocios el respeto a la ciencia.

Del mismo modo, todos los dirigentes políticos deben asumir también su responsabilidad, sin escuchar a los aduladores despreciables ni a los difamadores resentidos. Empieza una nueva vida. Hay que animar a este pueblo tan fiel, $\tan$ merecedor de felicidad, amante de la libertad como de sus dirigentes. Estos deben descender a los problemas del pueblo, a la vida tranquila y callada de estas gentes "en las que parece haberse refugiado la fidelidad y honradez, que tan raras se han vuelto en las clases superiores": D265. Entonces, seguro que tomarán la decisión de pensar más seriamente que nunca en cómo podrán ayudarles. El tiempo de las medias tintas y del dejar hacer y dejar pasar ha terminado.

Nuestros antepasados nos han trasmitido una memoria honrosa, noble e irreprochable, y estamos en las mejores condiciones para establecer el imperio de la razón y del espíritu, como dignos sucesores, frente a la razón de la fuerza. Nuestros descendientes nos exigen también ser dignos de nuestro pueblo, porque nobleza obliga, sin dejarnos arrastrar por una vida violenta, baja, bárbara y esclava. La Humanidad entera luchará para que "la gran promesa de un reino de la justicia, de la razón y la verdad en la especie humana", no sea un engaño vacío y pretencioso.

Todas las gentes de buena voluntad nos animan y conjuran a crear un futuro mejor lleno de dignidad, de magnanimidad y honor. Si no trabajamos con decisión por salir a flote, si se hunde nuestro pueblo, se malogra un poco más todo el mundo: "si vosotros os hundís, se hunde también con vosotros toda la humanidad sin esperanza de una restauración futura": D269. Sería una gran desgracia, para nosotros y para la Humanidad, que los grandes ideales de nuestro pueblo quedasen para siempre estériles o permaneciesen marchitos, pues nos jugamos la vida de nuestra nación y de nuestro mundo, su plenitud de paz, libertad, valor humano y social.

\author{
ANTONIO NATAL ÁlVAREz \\ IES Lancia (León) \\ DOMINGo NaTal Álvarez \\ Estudio Teológico Agustiniano (Valladolid)
}

